\title{
İkinci Şanslar: Bir Yükseköğretim Programını Tamamlamış ve Yeniden Örgün Lisans Eğitimine Başlamış Öğrenciler Üzerine Niteliksel Bir Araştırma
}

\author{
İsmail Burak Malkoç \\ Anadolu Üniversitesi, Sosyal Bilimler Enstitüsü, Sosyoloji Anabilim Dalı \\ ORCID ID: 0000-0001-8550-3085
}

\begin{abstract}
Özet
Türkiye üniversitelerinde açılan örgün lisans programlarına kaydolan öğrenciler arasında önceden bir yükseköğretim kurumundan mezun olmuş öğrencilerin oranı giderek artmaktadır. Literatürde bu öğrencilere ilişkin araştırmalarsa yok denecek kadar azdır. Bu araștırma bu öğrencilerin; öncelikle kim olduklarını, demografik, ekonomik ve toplumsal niteliklerini betimlemeyi, ardından önceki eğitimlerini, kariyerlerini neden geride bıraktıklarını ve yeni disiplinlerini hangi amaçlarla tercih ettiklerini ortaya koymayı amaçlamıştır. Niteliksel ve betimsel bir yöntem benimsenen bu araştırmada; ikinci defa üniversite okuma kararının öğrencinin sahip olduğu ekonomik ve toplumsal sermaye ile ilișkili olduğu ortaya konmuş ve önceki yükseköğretim disiplinlerine dair tercihlerini “yanlıș” olarak değerlendiren öğrencilerin bu tercihlerinde çoğunlukla eğitime dair hâkim toplumsal bakış açısını suçladıkları anlaşılmıştır. Bu öğrencilerin yeni yükseköğretim disiplinlerine dair tercihleriyse; idealindeki mesleğin eğitimini almak, kendini geliştirmek ve iş olanakları yüksek bir alana geçmek olarak ortaya çıkmıştır.
\end{abstract}

Anahtar kelimeler: yükseköğretim; ikinci üniversite; okul terk; yetişkin öğrenciler; eğitim sosyolojisi

\section{Second Chances: A Qualitative Study About Formal Undergraduate Students that Already have Higher Education Degrees in Advance}

\begin{abstract}
Among all the students enroll the undergraduate programs of Turkey, the number of students that already have higher education degrees in advance is growing gradually. However, in the literature, there is almost no research about these students. This study aims; to describe who these students are, their demographic, economic, and social qualities, and to reveal why they left their former educations and careers behind, and what their motivations are to prefer their current departments. Adopting qualitative and descriptive methods, this study revealed that the decision of enrolling university for the second time associated with the economic or social capital of the student and found out that the students principally blame the dominant perception of the society about education, for their "wrong" preference of their former departments. Further, the motivations of the students for the preferences of the current departments emerged as; to study for the dream occupation, to improve oneself, and to find better job opportunities.
\end{abstract}

Keywords: higher education; re-enrollment; drop out; nontraditional students; sociology of education

\section{Giriș}

Türkiye'de üniversite giriş sınavına başvuranlar arasında önceden bir yükseköğretim programını bitirmiş adayların oranının giderek artması dikkat çekicidir (Şekil 1), bu sayı 2018 yılında 191.644 kişi olarak kaydedilmiştir. Benzer şekilde Türkiye üniversitelerinde açılan örgün lisans programlarına yerleşen öğrenciler arasında da daha önce başka bir yükseköğretim programını bitirmiş öğrencilerin

*Yazışma Adresi / Address for Correspondence:

i. B. Malkoç, Email: malkocburak@gmail.com

Geliş Tarihi / Received Date: 04.01.2019

Kabul Tarihi / Accepted Date: 29.04.2019

Doi: $10.26701 /$ uad. 508556 oranı yıldan yıla yükselmektedir ve bu oran 2018 yılında yeni kaydolan tüm lisans öğrencilerinin \%7'sine -26.168 kişi- yaklaşmıştır (Şekil 2). ${ }^{1}$

$\mathrm{Bu}$ durum, çoğunlukla bir "istihdam problemi” olarak anlaşılmakta ve bir tür "çalışma hayatından kaçma" (T. Bora, 2017a, s. 52) veya "çocukluğu uzatma" (A. Bora, 2017a, s. 185) pratiği olarak tartışılmaktadır; bu anlatıya göre neo-liberal piyasanın zorlu koşullarında iş bulama-

\footnotetext{
'Illgili grafikler, araştırmacının ÖSYM'nin (Ölçme, Seçme ve Yerleştirme Merkezi) resmî internet sayfasından yayınladığı üniversite giriş sınavlarına dair sayısal bilgileri derlemesiyle oluşturulmuştur. 2018'e dek yapılan ÖSYS'ye (Öğrenci Seçme ve Yerleștirme Sınavı) dair bilgilere https://www.osym.gov.tr/TR,13046/2017. html bağlantısından ilgili tarihler aratılarak ulaşılmıştır. 2018 yılında ismi YKS (Yükseköğretim Kurumları Sınavı) olarak değiştirilen sınava ilişkin bilgilere ise https://www.osym.gov.tr/TR,15287/2018.html bağlantısından ulaşılmıştır.
} 
yan üniversite mezunu, "işsiz” görünmemek/kalmamak adına eğitimini uzatmaktadır. Benzer şekilde, bir işi olsa dahi onu beğenmeyen, "önceden belirlenmiş bir geleceği önünün kapanması olarak gören” (Erdoğan, 2017, s. 100) ve kendi seçtiği -yeni- bir meslekte kendini geliştirmeye çabalayan -şımarık- "orta sınıf işsizi" anlatısı da yaygındır. Toplumda da eğitimlerini uzatan -okulunu zamanında bitirmeyen, lisansüstü eğitime devam eden veya ikinci bir lisans programına kaydolan- öğrenciler bağlamında, “iş bulamadığı için okumaya devam ediyor" düşüncesinin hâkim olduğu söylenebilir; bu varsayımın bu öğrencilerin bir kısmı için doğru olduğu şüphe götürmez, ancak bu öğrencilerin bir diğer kısmının da -mutlu olsunlar veya olmasınlar- çalışmakta oldukları ve hatta mesleklerinde iyi yerlerde olabilecekleri gözden kaçırılmamalıdır, yani problem istihdam probleminden farklı bağlamlara da sahiptir.

Okulunu bitirmiş, diplomasını almış ve hatta iş bulup çalışmaya bile başlamış bir kimsenin, ailesine, ülkesine, kendisine faydalı olacağı yerde, tüm bu kazanımlarını geride bırakıp yeniden en az dört yıllık bir öğrencilik macerasına atılmasını toplum pek hoş karşılamaz. Öte yandan, bu kimselerin, yaygın kanaate ve görece ileri yaşlarına rağmen, tüm bu kazanımlarını geride bırakıp bir "ikinci şans" arayışıyla "hayallerinin peşinden" tekrar üniversite okumaya, yakınlarının -hem manevî hem de maddî- desteğini almadan karar vermeleri de mümkün değildir. Toplumsal konumlar; yani bu öğrencilerin en az dört yıllık eğitimlerini destekleyecek, sahip oldukları veya yakın çevrelerince onlara sunulacak -ekonomik, toplumsal veya kültü- rel- alt yapıları, gelirleri, birikimleri "ikinci şans" arayışı son derece ile ilișkilidir. En güçlü işsizlik sigortası olan aile (A. Bora, 2017a, s. 181), öğrenciye, muhtemelen mevcut işinden uzaklaşacağı bu macerada, yine destek çıkacaktır.

Peşinden yola çıkılan hayaller; "çocukluktan beri var olan idealler" de olabilir, "daha çok kazandıracak bir meslek edinmek" gibi ekonomik yapının etkilerinden ileri gelen, işsizlik, atanamama korkuları veya iş tatminsizliği sonucu yeni ortaya çıkmış hayaller de. "Çocukluk idealleri", gençlikte yapılan yanlış tercihler nedeniyle askıya alınmıştır; yanlış tercihlerin sorumluları ise, niyetleri iyi dahi olsa, onları kültür yerine tekniğe, hayallerindeki meslekler yerine gelecekte çok kazandıracak gözde mesleklere sürükleyen aileler, öğretmenler, eğitim sistemi veya neo-liberal ekonomidir (A. Bora, 2017b, s. 260).

İkinci kez üniversite okuyan bu kimseler, çoğunlukla "faydasız" veya "başarısız" kimseler olarak anlaşılmaktadırlar; ya üniversitelerini bitirmelerine rağmen topluma -veya yakın çevrelerine- faydalı olmayı reddetmektedirler ya da önceki üniversitelerinde veya hemen sonraki iş hayatlarında başarısız oldukları için bu yolu seçmişlerdir. Ancak, bizzat kendi hayal ve kararlarıyla atıldıkları muhtemel bu yeni üniversite hayatlarında ve sonrasında edinecekleri yeni mesleklerinde çok daha başarılı ve bilime, dünyaya veya ülkelerine çok daha faydalı olabilecekleri ihtimali göz ardı edilmektedir.

Bu bağlamda bu araştırma, gerçekleștirdiği mülakatlar eşliğinde; önceden bir yükseköğretim programını bitirmiş ve bugün tekrar örgün lisans eğitimine başlamış öğrenci-

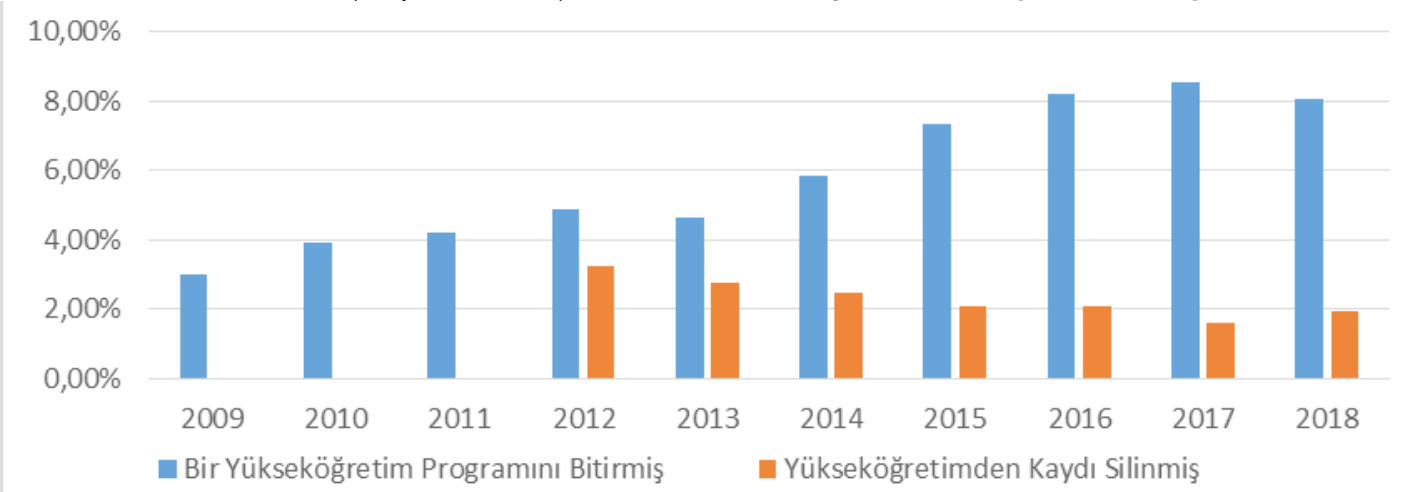

Şekil 1. Üniversite Sınavına Başvuran Önceden Bir Yükseköğretim Programını Tamamlamış veya Kaydı Silinmiş Adayların Toplam Başvurular İ̧̧indeki Oranları

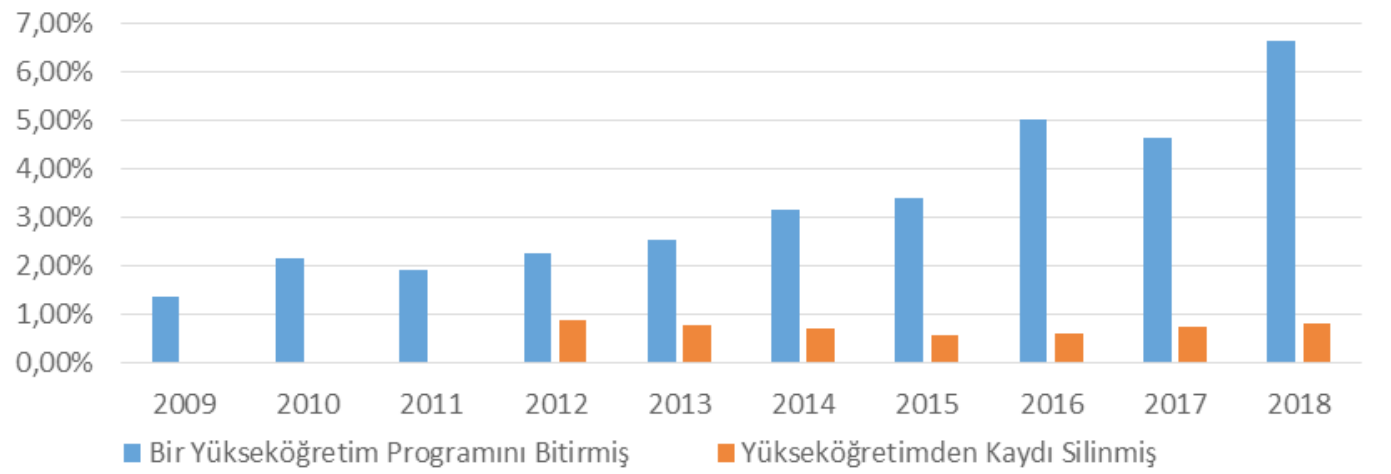

Şekil 2. Örgün Lisans Programlarına Kaydolan Önceden Bir Yükseköğretim Programını Tamamlamış veya Kaydı Silinmiş Öğrencilerin Toplam Kaydolanlar İçindeki Oranları 
leri incelemeyi, öncelikle bu öğrencilerin kim olduklarını, demografik, ekonomik ve toplumsal niteliklerini betimlemeyi, ardından bu öğrencileri ikinci kez üniversite eğitimi almaya ve önceki eğitimlerini, kariyerlerini terk etmeye iten sebepleri anlamayı, bu sebepler ve ikinci kez üniversite okuma kararları ile ekonomik ve toplumsal nitelikler arasında bir ilişki olup olmadığını aramayı ve ortaya koyacağı bu bulgularla literatürü zenginleştirmeyi, gelecekte yapılacak daha kapsamlı araştırmalara alt yapı ve temalar sunmayı amaçlamaktadır. Araştırma genelleştirilebilir veri üretme iddiasında değildir, ancak anlamaya çalıştığ toplumsal gerçekliği bizzat onu tecrübe eden öznelerin ağzından onların anlamlandırdıkları biçimde aktarmayı önemsemektedir. Ayrıca araştırma; üzerinde durduğu konunun yalnızca bir problem -ve özellikle de bir istihdam problemi- olarak görülmemesi gerektiğini, yeniden örgün lisans öğrenimine başlayan bu öğrencilerin, genel yargının aksine her zaman "eğitimlerini uzatan" veya "iş beğenmeyen” işsizler olmadıklarını, eski "yanlış" tercihleri değil, bu defa kendi "doğru” tercihleri doğrultusunda çıtıkları bu yolda belki de öncekinden çok daha başarılı ve faydalı olabileceklerini gösterebilmeyi ummaktadır.

\section{1. "Okulu Terk Etmek" Yerine "Kariyeri Terk Etmek"}

Öncelikle belirtmek gerekir ki; literatürde halihazırda bir diplomaya sahip olup yeniden bir örgün lisans eğitimine başlayan öğrencilerle ilgili araştırmalar yok denecek kadar azdır, halbuki okullarını terk eden veya terk etmek isteyen öğrencilere dair hem birçok kuramsal metne hem de sayısız araştırmaya rastlanabilmektedir. Bu probleme dair iki sebep öne sürülebilir: Birincisi, yeniden üniversite okuma olgusu Batı'da çok yaygın değildir ve Türkiye'de de hiç son yıllarda olduğu kadar yaygınlaşmamıştır. İkincisi ve daha önemlisi, eğitime dair hâkim bakış açısı, öğrencilerin kaç üniversite bitirdiklerinden çok kayıtlı oldukları üniversitelerini bitirip bitiremedikleriyle -istihdam edilip edilmedikleriyle- ilgilenmekte, eğer bitirememişlerse bunun sebeplerini ve dolayısıyla bu "problemi" çözmenin yollarını aramaktadır. Oysa bu durumun bir problem olarak görülmesi, yani kişinin ait hissetmediği bir mesleğin eğitimini veya bırakmak istediği bir üniversiteyi tamamlamasının yollarının aranması, o kişinin kendisi için de bir "problem", bir "zorlama” olarak ortaya çıkabilmektedir.

Eğitime dair bahsedilen bu hâkim -sosyolojik- bakış açısı "işlevselci" bakış açısıdır ve bu paradigmanın temellerini Durkheim'da (1956, s. 71) aramak yanlış olmayacaktır. Onun tanımıyla: "Eğitim, yetişkin nesillerin, toplumsal hayata henüz hazır olmayanlar üzerine etkisidir." Durkheim devam eder, eğitimin işlevi, "Kişinin ait olduğu toplumun, üyelerinde eksik olmaması gerektiğine kanaat getirdiği fiziksel ve zihinsel durumları aktarmaktır" (s. 70). Ayrıca Durkheim'ın (2014, s. 169) sosyolojinin görevini "toplumu biçimlendiren ihtiyaçları ortaya koymak" olarak belirlediği düşünülürse, eğitimin görevi de toplumun ihtiyacı olan bilgi ve pratikleri aktarmak, yani bir anlamda topluma faydalı toplum üyeleri yetiştirmek olarak an- laşılabilir, "Toplumun hayatta kalması ve uyum, ancak bu yoldan sağlanır” (Tezcan, 1985, s. 6). Sadece bu anlatım bile, okullarını terk veya mezun olmalarına rağmen eğitimlerine -yeniden- devam eden öğrencilerin, "toplumsal hayata hazır olmadıkları"na, "başarısız" veya "faydasız" olduklarına dair hâkim toplumsal görüşü açıllayabilmektedir. Durkheim'ın fikirlerini takip eden Parsons (1959, s. 267) da eğitimi, kişileri "gelecek yetişkinlik rollerinde $b a$ şarılı olmaları için hazırlayan” ve "toplumun yetişkin rol sistemi bağlamında insan kaynağı seçen ve yerleştiren” (s. 309), "toplumsal fayda" temelli bir kurum olarak kavrar. Peki, toplum ve eğitim bu yetişkinlik rollerini dayatmakta mıdır? Farklı bir rol, fayda tahayyülü olan gencin önüne konulan işlevsellik engelleri onu gelecekte faydasız ve başarısız kılabilir mi?

Toplumu akılcılaşan, sanayileşen ve bürokratikleşen bir yapı olarak kavrayan Weber de eğitimi benzer biçimde "gelecekte toplum için yüksek derecede eğitilmiş uzmanlar yetiştiren” bir kurum olarak görmüş ve onun temel işlevini "bireyin toplumsal statüsü bağlamında ileride dolduracağı yere hazırlamak" olarak ortaya koymuştur (Tezcan, 1985, s. 7). Ayrıca Weber'e göre "hızlı bürokratikleşen", yani modernleşen toplumların "kültürlü” değil "uzman" insan eğitme hedefi vardır (s. 218). Bottomore (1971, s. 33) da hemen aynı noktaya işaret eder: geleneksel toplumların aksine modern toplumlarda eğitim "edebiyattan" ziyade "fenne" yoğunlaşır. Bu çerçevede eğitimde işlevselci bakış açısına dair şu sonuçlara varılabilir: Birincisi, öğrencinin, -modern- topluma "faydalı" olacağı, "edebî" veya "kültürel” değil de mümkünse "fennî", "teknik" bir disiplinde "uzmanlık" kazanması istenmektedir. İkincisi "yeterlilik" veya "diploma” ile ilgilidir, öğrencinin bu uzmanlığa dair yeterliliğini bir an önce kazanması, yani disiplininde "başarılı" olması, olmasa bile okulunu “terk etmemesi”, çok önemli görülen "diploma”sını alması ve en kısa zamanda çalışmaya başlaması beklenmektedir. "Yeterlilik Enflasyonu" kavramıla bu durumu eleştiren Collins (2011, s. 228); “yükseköğretimin genişlemesi, temel olarak meslek piyasasında değișen yeterlilik [diploma] değerlerince mümkün olmuştur" demekte, yani "yeterlilik” -veya diploma- ile güncel meslek arzı -çoğunlukla teknik uzmanlık- arasında ilişki kurmakta, ayrıca diplomanın bir tür toplumsal statü göstergesine dönüştüğünü -daha doğrusu "düşük seviyeli" diplomaların "düşük statü” göstergelerine dönüştüğünü- belirtmekte (s. 229) ve bugün "yeterliliğin” bir ürün olarak alınır satılır hale geldiğinden, metalaştığından yakınmaktadır. ${ }^{2}$

Yukarıda belirtilen beklentiler ilk bakışta hiç de problemli görünmez; topluma faydalı olmak ve diploma önemlidir, diploma hem statü hem ekonomik kazanç anlamlarına gelir. Ancak bir öğrenci "fennî" değil "edebî” bir yolu tercih etmek istediğinde veya "fennî" bir yolda olsa dahi çeşitli sebeplerle mevcut okulunu terk etmek istediğinde, üzerinde "fayda", "başarı" ve "diploma" baskıları hissedecek, dolayısıyla toplum -veya öğrencinin çevresi- için ${ }^{2}$ Kavram Türkçe literatürde "Diploma Devalüasyonu” biçiminde de yer alabil- 
olmasa da öğrenci için bir "problem" ortaya çıkacaktır. Elbette tam tersi biçimde öğrenci daha yüksek bir kazanç veya statü elde etmek adına mevcut "kültürel" disiplinini terk edip "uzmanlık" kazanacağı yeni "teknik" bir disipline başlamak da isteyebilir, ki bu durum da bahsedilen hâkim toplumsal bakış açısından bağımsız değildir. İşte "okulu terk etme" konulu araştırmalar burada devreye girer, bu tür araştırmaların hemen hepsi öğrenciyi okula geri kazandırmak, okulu terk etme düşüncesini aklından çıarmak fikrine sahiptirler.

Durkheim'ın intihar ve bireyin toplumsal çevresiyle birleşememesi (entegre olamaması) arasında kurduğu ilişkiyi ${ }^{3}$, Tinto (1975, s. 92), okul terk ve öğrencinin "üniversitenin sosyal sistemine entegre olamaması" şeklinde eğitim literatürüne taşımıştır. Bu noktada Tinto "entegrasyon"u "toplumsal" ve "akademik" olarak ikiye ayırır: Toplumsal entegrasyon öğrencinin üniversitedeki çevresiyle etkileşimi ve birlikteliğini ifade ederken, akademik entegrasyon öğrencinin akademik performansı ve kariyer gelişimi ile ilgilidir (s. 94). Burada ayrıca "bireysel" ve "kurumsal" etkiler ayrımı göze çarpar; Tinto’ya göre öğrencinin yaşı, cinsiyeti, ailesi ve kültürel arka planı gibi bireysel (?) özellikleri toplumsal entegrasyonu ile ilgiliyken, önceki eğitimindeki ve mevcut başarısı gibi kurumsal meseleler akademik entegrasyona gönderme yapar (s. 95). Tinto (1982, s. 697-699) bir çözüm önerisi olarak üniversitelerin "okul terk (önleme) programları” yürütmeleri gerekliliğini savunmuş ve öğrencinin entegrasyonu adına üniversiteyi, yani "kurumsal" etkileri, ana faktör olarak kavramıştır.

Literatürde okulu terk etme sebepleri olarak "bireysel" ve "kurumsal" sebepler ayrımı yaygındır. Tinto gibi Rumberger (2001, s. 5-9) de "bireysel" ve "kurumsal" sebep ayrımını önermiş; bireysel sebepleri öğrencinin yaş, cinsiyet ve ırkının yanında bireysel bașarı durumunu da içerir biçimde tanımlarken, kurumsal sebeplere okul ile ilgili meselelerin yanında öğrencinin aile ve çevresinin etkilerini de dâhil etmiştir. Jordan, Lara \& McPartland'ın (1994, s. 8-9) okulu terk etmeye "çeken" ve "iten" etkiler kavramsallaştırmaları da aynı düşünce içinde değerlendirilebilir; okulu terk etmeye "iten" etkiler okul, yani kurum ile ilgilidir, "çeken" etkiler ise öğrencinin kurum dışındaki toplumsal çevresi (ailesi, arkadaşları) veya öğrencinin kendisi ile ilişkilidir. Finn'in (1989, s. 118-119) konu hakkında ortaya sürdüğü "frustration self-esteem" ve "participation-identification" ayrımı ${ }^{4}$ da benzer biçimde okunabilir; birincisi "gençlik hatalarını" ve okula veya eğitim görülen disipline dair "duygusal" bağlılığı da içine alan bir tür "bireysel sebepler" anlatısıdır, ikincisi ise kendisinden önceki "kurumsal sebepler" anlatısından pek farklı değildir.

Bu kuramsal anlatılar çerçevesinde okulu terk etme olgu-

\footnotetext{
mektedir. Daha geniş bir anlatım için bkz. Erdoğan, 2017, s. 77-78.

3 Durkheim'ın (2013, s.201-211) "bencil intihar" olarak tanımladığı bu intihar türü toplumsal -dinî, ailevî veya politik- bağları "gevşeyen" bireylerin intiharlarını açıklar.

${ }^{4}$ Literatürde ilgili kavramların Türkçe karşlıklarına rastlanmamışır, ancak "Kendine güven kırılması" ve "Katılım-özdeşleşme" olarak Türkçeleştirilebilirler
}

suna dair: Bireysel Sebepler olarak; yaş, cinsiyet, ikâmet gibi demografik niteliklerin yanı sıra, ailenin veya öğretmenin yanlış yönlendirmesi, disiplin hakkında öncesinden yeterince bilgi sahibi olmama (Yorke \& Longden, 2008) ve -çoğunlukla "gençliğin verdiği toyluk" nedeniyle- yanlış disiplin seçimi (Kember, 1990; Long, Ferrier \& Hagney, 2006) gibi nedenler gösterilmektedir. Kurumsal sebepler ise çoğunlukla üniversitelerin öğrencilerine sahip çıkamamaları ve rehberlik hizmeti eksikliği gibi problemlerle bağdaştırılmaktadır.

Okulu terk etme ile ilgili güncel birkaç araştırmaya değinmek gerekirse; Örneğin Bradley (2017), Bristol Üniversitesi'nde 11 farklı disiplinden öğrencilerle yaptığı niteliksel ve boylamsal araştırmasında en önemli okulu terk etme sebeplerinden birinin "15-18 yaşlar arasında yapılan yanlış kariyer seçimleri” olduğunu ortaya çıkarmıştır, hatta katılımcılardan bir tanesi araştırma sırasında eczacılık disiplinini terk edip psikoloji disiplinine başlamış ve artık çok daha mutlu olduğunu ifade etmiştir. Fortin, Sauve, Viger \& Landry (2016) Kanada'nın Quebec eyaletindeki muhasebecilik bölümlerindeki okul terk sebeplerini araştırdıkları çalışmalarında; önceden bir yükseköğrenim diplomaları olan öğrencilerin bölüme ilk defa kayıt yaptıranlara göre okulu \%10 oranında ve program ilk tercihleri olan öğrencilerin sonraki tercihi olan öğrencilere göre okulu \%8 oranında daha az terk ettiklerini göstermişlerdir. Meyer \& Marx (2014) Utah Üniversitesi'nde mühendislik bölümünü terk eden 4 öğrenci ile yaptıkları niteliksel çalışmalarında; her dört öğrencinin de " $m \ddot{u}$ hendisliğe ait hissetmedikleri”ni ortaya çıkarmışlardır ve her dört katılımcıları da mühendislik eğitimlerini bırakır bırakmaz farklı -çoğunlukla sosyal- bölümlerde yeniden lisans eğitimine başlamışlardır. Withey, Fox \& Hartley (2014) ise Keele Üniversitesi'nde okuyan ve daha önceden bir lisans programını terk etmiş 5 öğrenciyle niteliksel bir araştırma gerçekleştirmiş; öğrencilerin beklentilerinin karşılanmaması, rehberlik servisi eksikliği, önceden bölüm hakkında yeterince bilgilendirilmeme ve en çok da "bölüme ait hissetmeme" sebebiyle, biyoloji, kriminoloji, mühendislik gibi bölümleri terk edip sosyal bilim, müzik, edebiyat ve siyaset bilimi gibi bölümlere başladıklarını, dahası bu bölümlerde çok daha başarılı olduklarını ifade etmişlerdir. Türkiye'den bir örnek olarak Şimşek (2013) Harran Üniversitesi'nde 450 öğrenci ile yaptığ etme eğilimlerine dair niceliksel araştırmasında; mühendislik öğrencisi katılımcılarının \%59 oranla okulu terk etmeye eğilimli olduğu bulgusunun yanında, bölümünden memnun olmayanların \%67 ve bölüme isteyerek gelmeyenlerin de \%62 oranında okulu terk etmek istediklerini ortaya koymuștur.

Güncel araştırmalarda "disipline ait hissetmeme”, "disiplin hakkında yeterince bilgilendirilmeme" ve "yanlış kariyer seçimi" sebepleri öne çıkmaktadır; burada disipline ait hissetmeyişin yanlış tercihten ileri geldiğini ve disiplin hakkında yeterince bilgilendirilmemenin de yanlıș tercihin sebeplerinden biri olabileceğini söylemek yanlış ol- 
mayacaktır. Yanlıș tercihin, yalnızca öğrencinin veya büyüklerinin -bireysel- birer "hata"sı olmadığını da görmek gerekir; T. Bora (2017b, s. 260), eğitim sistemi veya genel anlamda neo-liberal ekonomik sistemin, öğrencileri gelecekte iş olanaklarının çok olacağına inandıkları "dönemin gözde mesleklerini tercih etmeye" yönlendirdiğinin altına çizmektedir. Zira hatayı öğrencide, ailesinde veya öğretmeninde aramak, tam da bireysel (?) tercihlerin yükünü, olumsuz sonuçlarını, yine bireylerin omuzlarına yükleme amacındaki neo-liberal sistemin (Bauman, 2015, s. 14) işine gelecektir.

Elbette bu araştırma okulunu terk eden öğrencileri konu almamaktadır, ancak ilk yükseköğretim eğitimlerinin ardından yeniden örgün bir lisans eğitimine başlayan öğrenciler bir anlamda -yaygın kanaatin aksine çok iyi entegre oldukları için değil, hissettikleri "diploma", "fayda" veya "başarı", "işsizlik” baskıları nedenleriyle- okullarını terk edememiş, ancak uygun şartlar sağlandığında "kariyerlerini terk ederek" belki de kendilerini ait hissettikleri bir mesleğin eğitimini almaya karar vermiş kimselerdir. $\mathrm{Bu}$ nedenle okul terk araştırmalarında ortaya konan sebeplerin, kariyerlerini terk eden bu öğrenciler için de ilk yükseköğretim tecrübeleri bağlamında geçerli olduğu söylenebilir. Ayrıca, yukarıda sıralanan araştırmalarda okullarını terk eden öğrencilerin çok kısa süre içinde yeni -ve çoğunlukla sosyal- bir disiplini tercih ederek yükseköğretime geri döndükleri görülebilmektedir; okulu terk edip başka bir üniversiteye başlamak ile mezuniyetin ardından başka bir üniversiteye başlamak birçok bakımdan farklı olgular olsalar da her iki tip öğrencinin benzer karakterlerde olacakları kuşkusuzdur.

\section{2. İkinci Şanslar: Mezuniyetin Ardından Yeni Bir Lisans Eğitimine Başlamak}

Halihazırda bir diploma sahibi olunmasına rağmen yeniden bir örgün lisans programına başlamak hayallerin peşinden çıkılan bir yol, ikinci bir şans arayışıdır. Bu yola çıan kimseler; çoğunlukla aile veya öğretmenlerinin yanlış yönlendirmesi sonucu, disiplin hakkında öncesinden yeterince bilgi sahibi olamadiklarından, ekonomik kazanç olasılıklarınca cezbedildiklerinden veya gençliklerinin verdiği "toyluk"la yanlış bir disiplin tercih etmiş, bu disiplinlere veya yükseköğretim kurumlarına kendilerini ait hissetmemiş, dolayısıyla "hep farklı bir bölüm okumayı hayal etmiş", ancak belki de "faydalı", "başarılı" olma veya en azından bir "diploma" sahibi olma baskıları nedeniyle okullarını terk edememiş, mezun olmuş ve hatta mezun oldukları disiplinle ilişkili bir meslekte çalışmaya bile başlamış ve nihayetinde uygun şartlar sağlandığında "kariyerlerini terk ederek" belki de kendilerini ait hissettikleri, çocukluk hayalleri olan bir mesleğin eğitimini almaya karar vermiş kimselerdir. Diğer yanda ise, çok sevdikleri

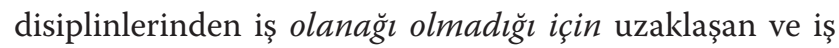
bulabilmek veya daha çok kazanabilmek gibi hayallerle bu maceraya atılan öğrenciler yer almaktadır.

Belirtildiği üzere, bu öğrencilerin hâkim anlayışa ve gö- rece ileri yaşlarına rağmen, tüm bu kazanımlarını geride bırakıp bu yola çıkmaları cesaret ister, cesaret ise uygun şartlar, yani kişinin en az dört yıllık yeni eğitimi boyunca yaşamını devam ettirip ettiremeyeceği gerçeği ile ilişkilidir. İkinci kere üniversite okumaya karar veren öğrenci; eğer ekonomik bir birikime sahip değilse, düzenli devam etmesi gereken bir işi var ve bırakamıyorsa, ailesine, evine, çocuklarına karşı sorumlulukları var ve yardım almıyorsa bu kararı çok kolay veremez. Fakat kişi tüm bu problemleri aşmasını sağlayacak ekonomik bir birikime sahipse, düzenli devam etmesi gerekmeyen ve iyi kazandıran bir mesleği varsa veya ailesi, eşi veya yakınlarınca destekleniyorsa ve elbette içinde olduğu kültürel çevre böyle bir kararı "yanlış" bulmuyor ve onu dışlamıyorsa, Bourdieu'nün terimleriyle ifade edilirse bu "alan"a girebilecek ekonomik, toplumsal ve kültürel "sermaye"lere sahipse ve bu karara uygun bir "Habitus"ten geliyorsa, bu kararı çok daha kolay verebilecektir.

Bourdieu (1986, s. 47-51) "sermaye" düşüncesini yalnızca ekonomik yanıyla kavramamış, onun haricinde; bir toplumsal gruba üyelikle ilişkili ve o gruptaki yakın olunan -destek verebilecek- kimseleri ifade eden "toplumsal" ve hem kişinin kültürel/teknik bilgilerini hem de sahip olduğu gelenek, inanç, yaşam biçimi gibi özelliklerini içeren "kültürel" sermaye tanımlarını yapmıştır. Bu sermayeler, doğuştan -yani "Habitus"ten- miras alınabildikleri gibi, tecrübelerden -mücadeleler sonucu yeniden üretilen $\mathrm{Ha}$ bitus'ten- de ileri gelebilirler ve her bir sermaye bir diğerinin artırılması adına farklı "alan"larda oynanan "oyun"larda -mücadelelerde- masaya yatırılabilir. Bourdieu'nün (Bourdieu \& Wacquant, 2016, s. 121) Habitus kavramı ise, onun kelimeleriyle; "Toplumsal eyleyicilerin tam anlamiyla akılcı olmadan, ... hesap yapmadan, ... planlar, tasarılar yapmadan” yaptıklarıdır, "bir yatkınlıklar, yani potansiyeller sistemi”dir (s. 125), bir anlamda kişinin içinde bulunduğu, farklı türdeki sermayelerini ve dolayısıyla davranış kalıplarını miras aldığı, ancak sürekli değişmeye de açık bir tür "toplumsal yapı" tanımıdır. Burada Bourdieu'nün (2015, s. 127-131) eğitimi, özellikle de yüksek veya orta sınıfların bakış açısından eğitimi, bu sınıfların sahip oldukları "yüksek" toplumsal ve kültürel sermayeleri, yani onların lehine işleyen hâkim Habitus'ü yeniden üreten, bir anlamda mevcut toplumsal eşitsizlikleri üst siniflar lehine muhafaza etmeye yarayan bir kurum olarak gördüğünü belirtmek gerekir. Üst ve orta sınıfa dâhil öğrenciler "ailelerince sadece eğitime devam etmeleri için cesaretlendirilmezler ... ayrıca ailelerinden toplum içinde aynı biçimde [ailelerin pratiklerini miras alarak] devam etmelerinin ethos'unu alırlar" (2012, s. 34). Ayrica Bourdieu'nün düşüncesinden yola çıkılarak her farklı sınıfın, sınıf Habitus'ünün, eğitime dair farklı beklentileri olduğu, farklı tür eğitim biçimlerini olumladığı düşüncesine de varılabilir.

Anlaşılacağı üzere; halihazırda bir diploma sahibi olunmasına rağmen yeniden bir örgün lisans programına başlama kararı, öncelikle bu kararı verecek kimsenin Ha- 
bitus'üne uygun düşmelidir, yani bu kimse bu kararı verirken en azından yakın çevresin daha önce bahsedilen faydalı, başarılı olma, eğitimini aldığı meslekte devam etme, yani diploma baskılarını hissetmemeli, destek görmelidir. İkincisi bu kimse bu dört yıllık eğitimi karşılayabilecek; ekonomik sermayeye, yani kişisel ekonomik birikime, düzenli devam etmesi gerekmeyen bir mesleğe veya yakın çevresinin ekonomik desteğine, yani bir tür "işsizlik sigortası olarak aile"ye (Erdoğan, 2017) ve toplumsal sermayeye, yani evine, ailesine, çocuklarına karşı günlük sorumluluklarında destek olacak, ona yardım edecek yakınlara ihtiyaç duyar. Dahası, eğer her "alan” bir mücadele içeriyorsa, bu kimse sermayelerini artırma hedefi güdecektir; yani bu dört yıllık yeni eğitimi sonucunda ya daha yüksek ekonomik gelir hedefliyordur ya da kendini ilgi alanında geliştirerek veya bu alandaki akademik, kültürel çevrelerin içine girmek suretiyle kültürel sermayesini artırmayı. Elbette bu karar; her sınıfın, Habitus'ün farklı eğitim beklentileri olduğu, farklı tür eğitim biçimlerini olumladığ düşünülürse ve modern toplumlarda hâkim anlayışın -hâkim Habitus'ün- "fennî” ve teknik "uzmanlık" eğitimlerini önde tuttuğu hatırlanırsa, eğer bu beklentilere uymayan bir kararsa, bu kimsenin içinde olduğu Habitus'e bir tür başkaldırısı anlamına da gelebilir, ki bu "başkaldırı" da yine sermaye birikimi ile ilişkili olacaktır. Neticede Türkiye'deki yükseköğretim öğrencilerinin anlamlı bir bölümü eğitimini alıyor oldukları disiplinlerden memnun değil görünmektedir (A. Bora, 2017b, s. 118), ancak bunların çok azı okullarını terk etmeye veya mezun olduktan sonra yeniden başka bir disipline başlamaya cesaret edebilmektedir (2018 yılında yalnızca 26.168 öğrenci, bkz. bu araştırma Şekil 2).

“Türkiye'deki yükseköğretim öğrencilerinin anlamlı bir bölümü eğitimini alıyor oldukları disiplinlerden memnun değil" önermesi cesur bir önerme olarak değerlendirilebilir, ancak bu durumun izleri Türkiye'deki yükseköğrenim öğrencileri üzerinde yapılan ve içlerinde "tekrar üniversitesi sınavına girmek ister misiniz?” sorusunu barındıran araştırmalardan rahatça sürülebilir. Birkaç örnek vermek gerekirse; Kızılçaoğlu'nun (2003) araştırmasında Sosyal Bilgiler Öğretmenliği Bölümü öğrencilerinden oluşan katılımcıların \%62 kadarı bölümü istemeyerek seçtiklerini ve bir kısmı da tekrar sınava girip alan değiştirmek iste- diklerini beyan etmişlerdir. Karakaş \& Özçelik (2014) 100 Evde Hasta Bakım Bölümü öğrencisiyle yaptıkları araştırmalarında katılımcıların \%28'i tekrar üniversite sınavına girmek istediklerini beyan etmiş ve programı seçme sebeplerine "aile önerisi", "puanımın yetmesi", "sınavsız geçiş” gibi cevaplar vermişlerdir. Beydağ, Gündüz \& Özer (2008) de 155 Sağlık Yüksekokulu öğrencisi ile yaptıkları araştırmalarında katılımcıların \%37 kadarının tekrar sınava girmek istediklerini ve \%40'ının da yalnızca puanları yettiği için bölümü tercih ettiklerini ortaya koymuştur. Örnekler yetersiz olsa da araştırmalara katılan öğrencilerin anlamlı bir kısmı disiplinlerini bir anlamda "rastgele" seçmiştir ve tekrar sınava girmek, disiplinlerini değiştirmek istemektedirler.

Bir diğer mesele ikinci defa üniversiteye başlayan bu öğrencilerin diğer öğrencilere göre yaşça ileri olmalarıdır; yükseköğretim literatüründe yer alan "yetişkin öğrenciler" veya "alışılmadık öğrenciler" olarak Türkçeleştirilebilecek "adult students" veya "non-traditional students" kavramları, temel olarak 18-22 aralığından daha ileri yaşlarda olan, evli, çalışan vb. lisans öğrencilerini ifade etmektedir (Bean \& Metzner, 1985, s. 486-489). Yabancı literatürde bu kavrama atıf yapan birçok araştırmaya rastlamak mümkündür; ancak bu araştırmalar ileri yaşlarında yeniden üniversiteye başlamaya karar veren öğrencilerden çok, çoğunlukla ilk yükseköğretim eğitimlerine devam eden ileri yaştaki öğrencileri, iş, ev ve ailelerine karşı sorumlulukları ve okula ne kadar devam edebildikleri -dolayısıyla okulu terk edip etmeyecekleri- bağlamlarında incelemektedirler. Bu araştırma ise, tüm bu sorumluluklarına rağmen yakın çevrelerinden aldıkları destek ile bu yola çıkan/çıkabilen "alışılmadık" öğrencileri konu almaktadır. Türkiye'de 22 yaşından büyük ve lisans programlarına yeni kaydolan öğrencilerin, tüm yeni kaydolan öğrencilere oranı son 4 eğitim yılıdır \%13’ten aşağılara inmemiştir (Şekil 3), dolayısıyla "alışılmadık öğrenci" kavramının gelecekte Türkçe literatürde de yer bulacağı öngörülebilir.

Daha önce bahsedildiği gibi literatürde halihazırda bir diplomaya sahip olup yeniden bir örgün lisans eğitimine başlayan öğrenciler ile ilgili araştırmalar yok denecek kadar azdır; ancak bir önceki başlıkta sıralanan "okul terk"

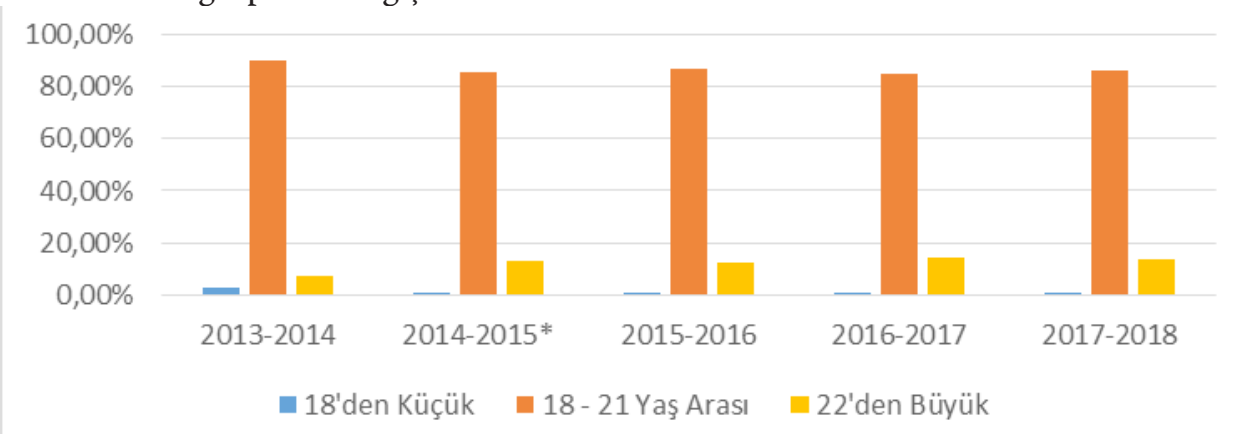

Şekil 3. Yaşlarına Göre Örgün Lisans Programlarına Yeni Kaydolan Öğrencilerin Oranları'

\footnotetext{
1 İlgili grafik; https://istatistik.yok.gov.tr bağlantısından ulaşılan, Yükseköğretim Bilgi Sistemi, Yükseköğretim İstatistikleri, "Yaşlara Göre Yeni Kayıt Olan Öğrenci Sayıları” başlığındaki verilerinin yıllara göre aranarak derlenmesiyle oluşturulmuştur.
} 
araștırmaları en azından okullarını terk edip farklı bir disiplinde yükseköğretimlerine devam eden birçok örnek olduğunu ortaya sermektedir. Yeniden üniversite okuma konusuna dokunan ancak çok da güncel olmayan bir örnek olarak Winter \& Harris'in (1999) Amerika Birleşik Devletleri'nin Kentucky eyaletinde 882 "geri transfer"5 öğrencisi üzerinde yaptıkları araştırma verilebilir; ki bu araştırma daha önce bir lisans diploması almış öğrencilerin yeni üniversitelerinde 4 üzerinden ortalama 0.5 puan daha yüksek not ortalamasına sahip olduklarını ortaya koyarak bu öğrencilerin "başarısız" kimseler oldukları mitine karşıt bir bulgu üretmiş ve farklı alanlardan gelen bu öğrencilerin çoğunlukla akademik kariyer yapma amacı taşıdıklarını ortaya koyarak da bu öğrencilerin kültürel sermaye artırma isteklerine temas etmiştir. Özbudak Akça, Çakır Aydın \& Halifeoğlu (2018) Dicle Üniversitesi mimarlık bölümü öğrencileri üzerinde yaptıkları araştırma ise Türkiye'den, konuya tam olarak değinen ve son derece güncel bir araştırma olarak göze çarpmaktadır. Araştırma önceden bir yükseköğretim diplomasına sahip ve mimarlık okumakta olan 40 öğrenci ve mezun 33 kişiyle gerçekleştirilmiştir. İkinci bir üniversite olarak mimarlıktan mezun olanların \%72'sinin okulu bitirir bitirmez mimarlık alanında çalışmaya başlaması araştırmanın belki de en önemli bulgusudur. Hâlâ bölümü okumakta olanlar ise önceden mezun oldukları bölümleri "çevre yönlendirmesi”, "puanı yettiği için”, "ekonomik getiri” gibi sebeplerle tercih etmiş, \%79'u önceki bölümlerinin beklentilerini karşılamadığını belirtmiş ve \%74'ü ise ikinci olarak mimarlık bölümünü "ideallerindeki meslek olduğu için" tercih ettiklerini beyan etmişlerdir.

Son olarak; eğitim ve "bilgi toplumu" bağlamında "yaşam boyu öğrenme" kavramından bahsetmek yerinde olacaktır. Bilgi toplumu sıklıkla sürekliliğini yitiren meslekler ile karakterize edilmektedir; "Bir kez öğrendikten sonra, yaşam boyu sürdürülen" işlerin yerini "geçici/sözleşmeli işler almaya başlamıştır” ve "çalışanlar, yaşamları boyunca yeni işlere uygun yeni hünerler kazanma ihtiyacı duymaktadırlar" (Bozkurt \& Baştürk, 2016, s. 408). Sürekli yenilenen bilgi, iş dünyasının talepleri doğrultusunda yaşam boyu eğitimi gerekli kılmaktadır, öğrenciler ise tek bir okulla sınırlı kalmayıp farklı okul ve kurumlardan kendi seçimleri doğrultusunda farklı eğitimler alabilmektedirler (Tezcan, 2002, s. 10-12). Ancak Güllüpınar (2017, s. 69) "çok az insanın yaşam boyu aynı işte çalışabildiği” bugün "sıklıkla iş değiştirmek zorunluluğu yapısal bir problem haline gelmektedir" (s. 67) diyerek mevcut durumu eleştirmekte, işverenlerin -elbette daha az maaş verme arzusu ile- "sürekli öğrenci kalacak" elemanlar aradıklarını belirtmekte ve çalışanların üniversite, kurs, staj, sertifika eğitimi bulma sorumluluğunun sistemden alınıp bireye

\footnotetext{
${ }^{5}$ Amerika birleşik Devletleri'nin bazı eyaletlerinde daha önce bir üniversite eğitimini tamamlamış veya yarıda bırakmış öğrencilerin yeniden üniversiteye başlamaları için uygulanan bir sistemdir. Türkiye'deki "dikey geçiş" sistemine benzemektedir, lisans ve ön lisans mezunların haricinde eğitimlerini yarıda bırakanlar da sistemden yararlanabilmekte, hem lisans hem de ön lisans bölümlerine yeniden kayıt yaptırabilmektedirler. Daha geniş bilgi için bkz. "Education Comission of the States" https://www.ecs.org/clearinghouse/01/18/77/11877.pdf
}

yüklendiğini vurgulamaktadır (s. 75). Bu durumda ikinci defa lisans eğitimine başlama olgusu; keyfi bir ikinci şans arayışı olmaktan ziyade mevcut toplumsal durumun getirdiği bir zorunluluk olarak ortaya çıkacaktır. Elbette bu tip bir arayış; Collins'in (2011) de işaret ettiği "meslek piyasası"nın ihtiyaçları paralelinde çoğunlukla teknik "uzmanlık” içeren, öğrencinin daha yüksek gelir elde etmeyi veya en azından bir gelir elde edebilmeyi, iş bulabilmeyi umduğu disiplinler doğrultusunda olacaktır ve ikinci bir lisans eğitimi olarak gençlik ideali olan bir disipline başlamaktan oldukça farklıdır. Zira problemin sıklıkla bir istihdam problemi olarak görülüşü de buradan ileri gelmektedir.

\section{YÖNTEM}

\subsection{Araştırma Modeli ve Katılımcılar}

Araştırma; "bir durumun, toplumsal ortamın ya da ilişkinin belirli ayrıntılarının resminin sunan" (Neuman, 2014, s. 53) betimsel ve karşılaştığı nitel verileri sunma ve sınıflandırma, yani gerçeği olduğu gibi tanımlama amacında$\mathrm{ki}$, "sıradan hayat pratiklerini incelemeye dalarak, bunlar içindeki birey deneyimlerinden yola çıkan" (Kümbetoğlu, 2012, s. 34) niteliksel bir araştırmadır. Katılımcılar araştırmanın kapsamına uygun lisans öğrencileri arasından amaçlı ve kartopu örnekleme yöntemleriyle seçilmiştir, daha önce en az bir yükseköğretim programını bitirmiş ve bugün tekrar bir yükseköğretim programına devam etmekte olan lisans öğrencileri soruşturulmuş ve sonucunda 6 katılımcıya erişilmiştir. Yalnızca 6 katılımcı; 26.168 kişilik bir evreni temsil etmeyi, genellenebilir sonuçlara erişmeyi ve nedensel sonuçlara varmayı mümkün kılmaz. Ancak bu araştırma niceliksel araştırmalara has bu kaygıları taşımamakta, katılımcılarının tecrübe ettiği gerçekliği doğrudan yansıtarak, kuramsal çerçevesinin de yardımıyla, gelecek araştırmalara temel oluşturacak bazı genel temalar ortaya çıkarmayı ve olası nedensel ilişkileri aramayı hedeflemektedir. Öte yandan, ilerleyen bölümlerde görüleceği üzere, yalnızca 6 katılımcı ile erişilen farklı ortak temalar ve birtakım genellikler dikkate değerdir. Katılımcıların yaşları, doğum yerleri, medeni durumları, çalışma durumları ve mezun oldukları ile araştırma sırasında devam ettikleri yükseköğretim programları Tablo 1'de gösterilmiştir.

Katılımcıların hepsinin kadın olması araştırmanın sınırlılıkları arasındadır, ancak hiç erkek katılımcı bulunamaması yeniden bir yükseköğretim kurumuna kaydolanların çoğunluğunun kadın olabileceği fikrini akla getirmektedir. Katılımcıların yaş ortalamaları 28'e varmaktadır ve en gençleri 24 en yaşlıları ise 35 yaşındadır, bu durum "alışılmadık öğrenciler” konseptini akla getirir, ancak buna rağmen katılımcıların yalnızca ikisi evli olup hiçbiri çocuk sahibi değildir ve yalnızca ikisi çalışıyor olduklarını belirtmiştir, yani ilk bakışta hiçbirinin okullarına devam etmelerini engelleyecek bir sorumlulukları yok gibi görünmektedir. 
Tablo 1. Katılımcılar, Demografik Özellikleri ve Yükseköğretim Bilgileri

\begin{tabular}{|c|c|c|c|c|c|c|c|}
\hline$\underset{\underline{\Sigma}}{\stackrel{\bar{\Xi}}{\sum}}$ & 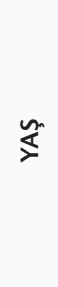 & 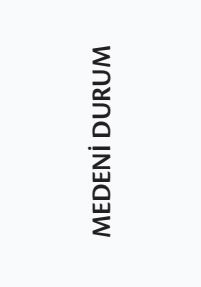 & 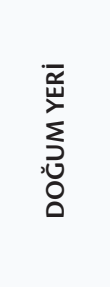 & 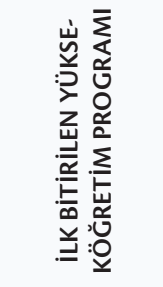 & 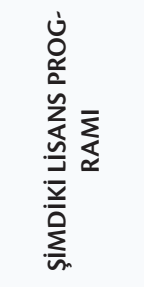 & 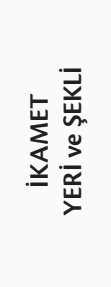 & 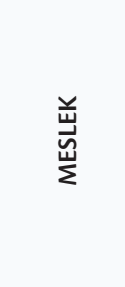 \\
\hline Esra & 24 & Bekâr/Çocuksuz & Eskişehir & Siyaset Bilimi & $\begin{array}{c}\text { Okul } \\
\text { Öncesi Öğr. }\end{array}$ & $\begin{array}{l}\text { Eskişehir } \\
\text { Aile yanı }\end{array}$ & Çalışmıyor \\
\hline Demet & 26 & Bekâr/Çocuksuz & Eskişehir & $\begin{array}{l}\text { Sivil Havacılık } \\
\text { (Ön Lisans) }\end{array}$ & $\begin{array}{l}\text { Sanat } \\
\text { Tarihi }\end{array}$ & $\begin{array}{l}\text { Eskişehir } \\
\text { Aile yanı }\end{array}$ & Çalışmıyor \\
\hline Ece & 27 & Bekâr/Çocuksuz & İstanbul & Ekonomi & $\begin{array}{l}\text { Sanat } \\
\text { Tarihi }\end{array}$ & $\begin{array}{l}\text { İstanbul } \\
\text { Aile yanı }\end{array}$ & Editör \\
\hline Buket & 29 & Evli/Çocuksuz & Kocaeli & Sosyoloji & Psikoloji & $\begin{array}{l}\text { İstanbul } \\
\text { Eşiyle }\end{array}$ & Çalışmıyor \\
\hline Hande & 35 & Evli/Çocuksuz & İstanbul & Diş Hekimliği & Arkeoloji & $\begin{array}{l}\text { İstanbul } \\
\text { Eşiyle }\end{array}$ & Diş Hekimi \\
\hline Çağla & 27 & Bekâr/Çocuksuz & İstanbul & İşletme & $\begin{array}{c}\text { Okul } \\
\text { Öncesi Öğr. }\end{array}$ & $\begin{array}{l}\text { İstanbul } \\
\text { Yurt }\end{array}$ & Çalışmıyor \\
\hline
\end{tabular}

\subsection{Verilerin Toplanması ve Veri Analizi}

Veriler; yüz yüze veya çevrimiçi yarı-yapılandırılmış mülakatlar ile toplanmış, görüşmeye razı olmayan 2 katılımcıya ise doldurmaları için yapılandırılmış açık $u c ̧ l u$ soru formları gönderilmiştir. Mülakatlar üç ana bölümden oluşmuştur. İlk bölüm katılımcıların demografik, ekonomik ve kültürel niteliklerine dairdir; bu bölümde katılımcılara yaşları, cinsiyetleri, çalışma ve medeni durumlarının ikinci kere üniversiteye girme kararları ile ilişkisine dair sorular sorulmuştur. İkinci bölüm katılımcıların mezun oldukları ilk yükseköğretim disiplinlerine hangi sebeplerle başladıkları, deneyimleri, başarı durumları ve bu disiplini neden terk etmediklerine dair soruları içermektedir. Son bölüm ise katılımcıların devam etmekte oldukları örgün lisans disiplinlerine hangi sebeplerle başladıkları, deneyimleri, başarı durumları ve gelecek planlarına dair sorulardan oluşmaktadır. Yüz yüze ve çevrimiçi mülakatlar bir ses kayıt cihazıyla kaydedilmiş, yazıya dökülmüş, -yapılandırılmış formlardan gelen veriler ise doğrudan alınmış- ardından hem literatürde sıralanan hem de yeni ortaya çıkan temalar bağlamında analiz edilmiş, sınıflandırılmış ve durum betimlenmiştir.

Araştırmanın ilk bölümünde katılımcıların yaşları, cinsiyetleri, ekonomik durumları ve aile veya eşlerinden aldıkları destek, yani ekonomik, toplumsal ve kültürel sermayeleri ile ikinci defa üniversiteye başlama kararları arasındaki ilişki analiz edilmiştir. Böylece bu öğrencilerin kim olduklarına, yani demografik, ekonomik ve toplumsal niteliklerine dair bir betimleme ortaya konmuş ve bu öğrenciler arasındaki benzerlik veya farklılıklar incelenmiştir.

Araştırmanın ikinci bölümünde ise katılımcıları ikinci kez üniversite eğitimi almaya ve önceki eğitimlerini, kariyerlerini terk etmeye iten sebepler anlaşılmaya çalışılmış, bu sebepler ile ekonomik ve toplumsal nitelikleri arasında bir ilişki olup olmadığını aranmıştır. Bu noktada araştırmanın temaları olarak: 1- Katılımcıları ilk yükse- köğretim programlarını tercih sebepleri olarak; isteyerek, iş olanakları (Özbudak Akça vd., 2018), gençliğin verdiği toyluk (Bradley, 2017; Finn, 1989; Kember, 1990; Long vd., 2006), 2- İlk yükseköğretim programlarını -yanlış- tercihe iten etkiler olarak; aile veya eğitim sistemi tarafından yanlış yönlendirilme (Karakaş \& Özçelik, 2014; Özbudak Akça vd., 2018; Rumberger, 2001; Tinto, 1975), disiplin hakkında yeterince bilgilendirilmeme (Whithey vd., 2004; Yorke \& Longden, 2008), puanı öyle yettiği için (Beydağ vd. 2008; Karakaş \& Özçelik, 2014; Özbudak Akça vd., 2018), 3- İkinci bir üniversite programına başlamaya iten sebepler olarak; önceki disipline ait hissetmeme (Finn, 1989; Meyer \& Marx, 2014; Whithey vd., 2004), iş hayatındaki tatminsizlik, işsizlik endişesi ve 4- Mevcut devam edilen disiplini tercih sebepleri olarak da; ideal meslek oluşu (Özbudak Akça vd., 2018), kendini geliştirme ve yine iş olanakları belirlenmiştir. Son olarak katılımcıların okumakta oldukları yeni disiplinlerine dair gelecek planları aktarılmış ve bu disiplini tercih etme sebepleri ile ilişkisi tartışılmıştır.

\section{BULGULAR}

\subsection{Demografik Nitelikler: Habitus, Sermaye ve Yeniden Üniversite Okuma Kararı}

Bahsedildiği üzere bu bölümde katılımcıların yaş, cinsiyet, çalışma durumu, medeni ve ekonomik durum gibi niteliklerinin ve yakın çevrelerinden aldıkları desteğin, yani ekonomik, toplumsal ve kültürel sermayelerinin, ikinci kere üniversite okuma kararlarıyla ilişkili olup olmadığ araştırılmıştır. Bu soruların ilki katılımcıların yaşları ile ilgilidir ve burada ortaya; "Daha genç olsaydım bu kararı vermezdim", "Daha yaşlı olsaydım bu kararı vermezdim” ve "Bu kararı verdim çünkü gençtim” ana temaları çıkmıştır. "Daha genç olsaydım bu kararı vermezdim" teması ise en dikkate değer temadır. Örneğin Esra (24), "Daha genç olsam bu kararı vermezdim. (...) böyle bir iş garantili bir mesleğe yönelmezdim” demiş, Buket (29), "29 yaşımda kim olduğumu, ne istediğimi gençliğin hülyasından 
kopmuş bir şekilde daha sağlıklı anladım.” diyerek ileri yaşının kararındaki önemine değinmiş ve Hande (35) ise "Daha genç olsaydım bu kararı alır mıydım bilemiyorum, (...) daha zor olurdu. Biraz kendini tanımakla, mutluluğu aramakla ilgili olduğundan (...) şimdi tam zamanıydı." sözleriyle Buket'in anlatısını yinelemiştir. Öte yandan; Ece (27) "Otuzlu yaşlarımda olsaydım belki geç kaldığımı düşünebilirdim.” ve Çağla (27) “Tabii insan bir düşünüyor. Bu yaşta okusam ne zaman mezun olurum, ne zaman işe girerim..." sözleriyle biraz daha geç kalsalar tekrar üniversiteye girmeyeceklerini belirtmiş ve karşıt bir tema inşa etmişlerdir. Demet (26) ise bu karşıtlıktan bağımsız olarak, kabin hizmetleri ön lisansını bitirip çalışmaya başladığı dönemi "Henüz çalışma yaşı değilmiş gibi geldi bana." biçiminde anlatmış, "O sebeple biraz da tekrar üniversite okumak istedim.” demiş ve kararında gençliğinin önemini vurgulamıştır.

Soruların ikincisi katılımcıların cinsiyetlerinin ikinci kere lisans okuma kararlarına etkisi ile ilgilidir ve burada "Erkek olsam bu kararı vermezdim" ve "Erkek de olsam bu kararı verirdim" temaları öne çıkmıştır. Esra "Erkek olsam bu kararı vermezdim. Eee ${ }^{6} .$. İş hayatına atılmayı isterdim", Ece "Erkekler için çok daha zor (...) Kimsenin bir kadından ev geçindirme beklentisi yok", Buket "Eee... Eğer erkek olsaydım ve askerlik, evlilik gibi engellerim olsaydı... Ailem ve kız arkadaşım herhalde bu denli destek olmazdı bana" ve Çağla "Erkek olsam da (...) yeni kazandığım bölüm (...) iş olanağı daha yüksekse okurdum.” sözleriyle bu kararın erkekler için çok daha zor olduğunu belirtmişlerdir. Öte yandan, Demet "Yine bu kararı alırdım. Cinsiyetle alakalı olduğunu düşünmüyorum. Tamamen kişisel." demiş ve Hande de "Cinsiyet kalıplarına inanan biri değilim. Yani erkek olsaydım da bu kararı verirdim diye düşünüyorum." sözleriyle onu desteklemiştir.

Bir sonraki soru ise katılımcıların medeni ve ikamet durumları ile ilgilidir; yani katılımcılar bu ikinci üniversite eğitimlerinde aile ve eșlerinden destek almakta mıdırlar yoksa tüm sorumlulukları kendileri mi üstlenmektedirler anlaşılmaya çalışılmıştır. Katılımcıların hemen tümünün eş ve ailelerinden maddi veya manevi destek görmeleri dikkate değerdir. Esra "Ailemle yaşamam daha iyi, daha kolay. Ailem bana destek oluyor." ve "Beni yönlendiren zaten annem oldu!" ve Çağla tekrar üniversite okuma kararını kastederek "En büyük destekçim annemdi" demekte ve Demet önceki çalışma hayatını kastederek "Ailem gel artık yapamıyorsun dedi" sözleriyle ailesinin onu tekrar sınava girmeye yönlendirdiğini belirtmektedir. Evli katılımcılardan Hande eşini kastederek "Biz üniversite s1navına beraber girdik! (...) desteğini hiç esirgemiyor sağ ${ }^{6}$ Katılımcılar, mülakatlar sırasında sık sık duraksayabilmekte ve ne diyeceklerine karar verecekleri anlarda hepimizin âşina olduğu "eee", "॥", "aaa” benzeri kısa sesler çıkarabilmektedirler. Araştırmada katılımcıların sözlerinin doğrudan aktarılmasına özen gösterilmiş ve bu nedenle ilgili kısa düşünme sesi, ses kayıtlarından metne "eee" biçiminde yansıtılmıştır. Duraklama ve düşünme ânları bu araştırma için önemli birer veri oluşturmamaktadır; ancak hem katıımcıların seslerinin okur tarafından daha samimi bir biçimde duyulabilmesini mümkün kılmak için hem de gelecek araştırmaların bu duraklamaları veri olarak kullanma ihtimallerini hesaba katma sorumluluğuyla, metinde aynen aktarılmışlardır. olsun." demekte ve Buket de benzer şekilde "Fikir eşimden çıktı." ve "Psikolojinin tam bana göre olduğunu ve tekrar okumam gerektiğini söyledi." sözleriyle Hande'nin anlatısını desteklemektedir, ancak Buket "Ev hanımlığım başladı. Eşim çok geç saatlere kadar çalıştığından ev işlerinin çoğunluğu benim omzumda. Zamanımı daha fazla kitap ya da makale okuyarak, alanımla ilgili daha fazla eğitim ya da seminere katılarak geçirebilirdim." sözleriyle sorumluluklarının ağırlığından da bahsetmeden geçmemektedir. Katılımcılar arasında yalnızca Ece ailesinden destek görmediğini "Durumu bir oyun olarak algıladıkları için uzun süre ses çıkarmadılar. Annem neredeyse yok sayıyordu... Eee... Falan bir noktada kabullendiler." sözleriyle açılamıştır, ancak sevdiği bir işinin olduğunu ve desteğe ihtiyaç duymadığını da belirtmiştir.

Görüleceği üzere; katılımcılar cinsiyetlerinde bu kararın etkili olduğunu vurgulamalarına rağmen çoğunlukla yaşlarını önemsememektedirler, ancak hepsi bir şekilde aile ve eşlerinin desteğini alarak görece geç yaşlarına rağmen iş ve ev sorumluluklarından sıyrılabilmiş, destek almasalar da kendi çalışma (meslek) zamanlarını ayarlayabilen ve gelirleri de iyi olan öğrencilerdir. Hande, diş hekimidir, aylık gelirinin on bin lira olduğunu ve çalışma saatlerini ayarlayabildiğini söylemiştir, ailesinden destek görmeyen Ece ise editörlük yapmaktadır ve kısmen evden çalışabilmektedir. Yani katılımcıların her biri tekrar üniversite okumak için gerekli ekonomik sermayeye sahiptir; Ece ve Hande düzenli devam etmeleri gerekmeyen meslekleri ve yüksek sayılabilecek gelirleri ile eğitimlerini sürdürmektedirler. Esra, Demet ve Çağla ailelerince ekonomik olarak desteklenmektedirler ve Buket'in eşinin geliri Buket'in eğitimini sürdürmesi için yeterlidir, aileler işsizlik sigortası işlevlerini yerine getirmektedir. Hemen her katılımcı gerekli toplumsal sermayeye de sahiptir; Esra, Demet ve Çağla'nın aileleri ev içi sorumluluklarda yardımcı olmaktadır, Hande'nin eşi ile beraber ev işlerini bölüşmektedir, Ece sorumluluklarını kendi kendine hallediyor görünmektedir ve bir şikâyeti yoktur, Buket ise ev işlerinden şikayet etse bile eşinin genel desteğini olumlu bulmaktadır. Dahası, hemen her katılımcı bu kararı vermelerine uygun bir Habitus'ten gelmektedirler; hemen hepsi ikinci kere üniversite okuma fikrinin yakınlarından çıktığını veya yakınlarının bu fikirlerine koşulsuz destek verdiklerini dile getirmişlerdir. Ece ise böyle bir destek görmese bile ailesinin bu fikre zamanla alıştığını söylemiş, yani bir anlamda kendi Habitus'ünü dönüştürmüștür.

Konunun toplumsal cinsiyet bağlamı da dikkat çekicidir; katılımcılar arasında hiç erkek olmaması bir yana, neredeyse tüm katılımcılar erkekler için ikinci kere üniversite okuma kararının zorluğundan bahsetmişlerdir, yani hâkim işlevselci eğitim bakış açısı "başarı", "fayda” ve "diploma” bağlamlarında erkekler üzerinde çok daha yoğun baskı oluşturuyor gibi görünmektedir. A. Bora'nın (2017b, s. 185) da işaret ettiği, eğitim ve "çocukluğun" uzatılmasının toplumun bakış açısından kadınlar bağlamında çok daha kabul edilebilir olduğu bir gerçektir. İleri yaş me- 
selesinin ise olumsuz değil aksine olumlu bir etkisi var gibidir; katılımcılar -çoğunlukla- daha genç olsalar -yine başarı, fayda, diploma ve hatta teknik "uzmanlık” baskılarını düşünerek- bu kararı veremeyeceklerini belirtmişlerdir. Burada, genellikle okul ve sorumluluklar bağlamında olumsuzluk çağrıştıran "alışılmadık öğrenci” kavramı, bu öğrenciler için çok da anlamı olmadığı söylenebilir.

\section{2.Önceden Mezun Olunan Yükseköğretim Programları ve "Kariyerin Terk Edilmesi"}

Bu bölümde katılımcılara genel olarak önceki yükseköğretim eğitimleri ile ilgili sorular sorulmuş, önceki disiplinlerini tercih etme sebepleri, orada yaşadıkları tecrübeler ve neden bugün bu kariyeri terk etmelerine rağmen geçmişte okullarını terk etmedikleri anlaşılmaya çalışılmıştır. Katılımcıların önceki üniversite disiplinlerini tercih etme sebepleri olarak, literatürden de ileri gelen; "isteyerek", "gençliğin verdiği toyluk", "puanım yettiği için” ve "iş olanakları" sebepleri/temaları öne çıkmaktadır. Örneğin Esra, siyaset bilimi disiplinine çok isteyerek başladığını belirtmiş ve "O zamanki Esra olarak cevap veriyorum, çok... siyaset bilimiyle ilgiliydim, sosyal bilimler lisesi çıkışlıyım zaten, ilgim vardı lisede, ki tatmin de oldum bölümü okuduktan sonra." demiştir, kendisi önceki disiplinini isteyerek tercih eden tek katılımcıdır. Çağla, önceki disiplini olan işletmeyi "Puanım ona yetiyordu diye gittiğim bir bölümdü işletme. O zamanlar katsayı falan vardı ve, eee, (...) X üniversitesi işletme bölümünü yazdım. Kazandım, okudum öyle." diye tarif etmekte, puanım yettiği için temasına açıkça gönderme yapmaktadır. Buket, önceki disiplini olan sosyolojiyi şimdiki disiplini olan psikoloji ile karşılaştırarak “Travmalarla uğraşarak çözüm yolları aramaktansa, eee, daha genele dönüp tüm insanlığa, eee, topluma faydalı olmak istedim. Gençlik hayaliydi." demekte ve hem gençliğin verdiği toyluk temasına gönderme yapmakta hem de hâkim toplumsal algının "faydalı" olma baskısını hissettiğine doğrudan işaret etmektedir. Demet ve Ece'ye ise önceki disiplinleri iş olanakları nedeniyle çekici gelmiştir: Demet tercih yaparken ne istediğini tam olarak bilmemektedir ve mezunu olduğu kabin hizmetleri ön lisansını tercih sebebi için "Eee... İstihdamın açık olması. Çok iş olanağı olması. (...) bölüm, zaten yeni açılmıştı, kulağa güzel geliyordu" cümlesini kurmaktadır. Ece ise "Nasılsa istediğim bölümü okuyamayacağım için bari seçeneğim olsun dedim. (...) En uygunu o göründüğü için de ekonomi seçtim." demektedir.

Katılımcılar sebeplerini öne sürmüşlerdir, ancak geçmişte yaptıkları bu tercihleri bugün -doğru veya yanlış- nasıl görmektedirler? Katılımcılar bu soruyu hemen hep birlikte "yanlış" olarak cevaplamakta ve Demet, "Kesinlikle yanlış bir tercihti”, Ece, “Kesinlikle yanlıştı., Buket ve Hande basitçe "Yanlıștı." ve Çağla "Bana uygun değildi, Yanlış bir tercihti." cümlelerini kurmaktadırlar. Yalnızca önceki disiplinine isteyerek başladığını belirten Esra, "Yanlış değildi. Aile yönlendirmesi falan değil tamamen kendi isteğim." sözleriyle disiplini tercih sebebine tutarlı bir anlatı oluşturmuştur.

O halde katılımcılar bu yanlış tercihleri için kimleri suçlamaktadırlar? Burada da yine literatürden ileri gelen; "aile/ sistem yönlendirmesi" (yani yanlış yönlendirilme) ve "disiplin hakkında önceden yeterince bilgilendirilmeme" temaları öne çıkmaktadır. Örneğin Ece açık bir biçimde "Aslında psikoloji okumak istemiştim ama ailem baskı kurarak yolumu kesti" diyerek ailesini, Hande "Eğitim sisteminin yönlendirmesinin yanlış olduğunu görmek lazım. Ailemin tutumunun da bu yanlışı perçinlediğini söyleyebilirim." diyerek sistem ve ailesini, Buket ise "Dershanedeki rehberlik hocam ben ve birçok kişiyi kendi mezun olduğu bölüme [sosyoloji] gönderdi, iş imkanının çok fazla olduğunu anlatarak. Böyle bir şey yok. (...) Rehberlik hocamı suçluyorum. (...) Beni daha iyi yönlendirebilirdi." demekte ve öğretmenini, yani sistemi suçlamaktadır. Yani Ece, Buket ve Hande genç yaşlarında yaptıkları bu tercihlerinde yönlendirildikleri ve hatta yanlış yönlendirildiklerini ifade etmektedirler. Öte yandan Demet aykırı bir anlatı sunarak, "Ailemi suçluyorum. Yönlendirilmemde eksiklik olduğunu düşünüyorum. Yani, eee, belki de biraz daha yönlendirici olabilirlerdi. Serbest bırakılmak... O yaşta doğru kararları yalnız almak..." cümleleriyle yönlendirilmeme veya bilgilendirilme eksiğine işaret etmekte ve "Keşke daha önceden bu bölümü okuyan biriyle konuşup tecrübelerini dinleyebilseydim." dileğiyle anlatımını kuvvetlendirmektedir. Çağla basitçe önceki disiplini olan işletme ile ilgili "Yapılması gereken şeyleri yapmadım. Sevemediğim için sanırım bilemiyorum... Bana uygun değildi." demektedir, bir anlamda yalnızca kendini suçlamaktadir. Siyaset bilimine isteyerek giren Esra ise zaten disiplinini severek tamamladığı için bu temalara uymamaktadir.

Katılımcıların ikinci kere üniversite okuma kararları çoğunlukla ilk disiplinlerine ve mesleklerine duydukları bu isteksizlikten ileri gelmektedir, ancak elbette isteksizliğin sebepleri de farklıdır. Katılımcılara tekrar üniversite sınavına girmeye ve yeniden bir örgün lisans programına kayıt olmaya niçin ve ne zaman karar verdikleri sorulmuştur. Yanıtlar; "iş hayatındaki tatminsizlik" ve "ait hissetmeme" temalarını hatırlatmakta ve bunlara ek olarak bilgi toplumu ve yaşam boyu eğitim olgusunun baskısı düşüncesinden ileri gelen "gelecek/iş kaygısı" temasına yönlendirmektedir. İş hayatında tatmin olamadığını ifade eden eski kabin görevlisi Demet işinden şöyle yakınmaktadır:

"O dönem, hostesken, yani o mesleği yaparken, rahatsız olduğum şeylerden biri insanlarin sadece parfümlerden, makyaj malzemelerinden, gittikleri yerlerden, eşlerinden bahsetmeleriydi. Çok rahatsız edici. Konuşulabilecek bir gazete başliğı, bir kitap, işte bir sinema filmi falan gibi entelektüel birikimleri olmayan insanlar."

İşletme mezunu olan Çağla "İkinci üniversite fikri ça- 
lışırken çıktı. KPSS’ye (Kamu Personeli Seçme Sınavı) çalışırken YGS'ye (Yükseköğretime Geçiş Sınavı) de girdim. YGS sonucuyla bu bölümü kazanabildiğimi gördüm ve tekrar üniversite fikri ortaya çıtı. Nedeni önceden de söylediğim gibi çalıştığım işi sevmemem. Mali müşavirin yanında çalışıyordum." demekte, yani hem Demet hem Çağla iş hayatındaki tatminsizlik vurgusu yapmaktadırlar. Bu konuda öne çıkan tema olan ait hissetmeme teması ise; Ece tarafından "Başka bir bölüm okumayı hayal meyal düşünsem de bitirmeden kalkışmak üniversitemin konumu yüzünden olası değildi zaten." ve Buket tarafından "Yüksek lisansla psikolog olamayacağımı öğrendiğimde bu kararı aldım. ...bunu yapabileceğimi biliyordum." biçimlerinde vurgulanmış, ancak en vurucu anlatıyı Hande inşa etmiştir:

"I̧çime sinmeyen bir şeyler hep vardı.
Tam adlandıramıyordum. Ancak diş
hekimi olmak maddi anlamda cazip ge-
liyordu. Ben de maddi yeterliliğin mutlu
olmak için yeterli olacağını düşündüm.
Ama ilerleyen süreçte öyle olmadığını
gördüm. (...) Yolum bu mu olmalıydı?
Sadece iyi para kazanıp sistemin çark-
larını hızlandırmak beni mutlu edecek
miydi? Sonunda hayatın bundan daha
fazlası olması gerektiği kanaatine var-
dım."

Siyaset bilimini severek bitiren Esra ise ayrı bir probleme, temaya işaret etmektedir: iş kaygısı.

"Eee ilk başta tabii ki de çok mutluydum, ama ylllar geçtikçe bir hayal klrıklı̆̆ına uğradım. Bu hayal kırıkllğı... Son yılımda başladi. Çünkü, bu sürecin sonunda bir KPSS gerçeğiyle yüzleștim. O gerçek beni hayal kırıklığına uğrattı. (...) çok çok yüksek puanlar gerekiyor atanmak için."

Esra bu sözleriyle yeniden lisans okuma kararını iş bulamama problemine bağlamaktadır ve bu nedenle okul öncesi öğretmenliği tercihini yapmıştır. Görüleceği üzere hemen tüm katılımcılar önceden mezun oldukları disiplin tercihlerini yanlış olarak nitelendirmekte ve suçu çoğunlukla aile veya sistem tarafından yanlış yönlendirilme probleminde aramaktadırlar. Sistem -eğitim sistemi veya genel anlamda neo-liberal ekonomik sistem-, aile veya ögrretmenler onları -maalesef- "dönemin gözde mesleklerini tercih etmeye” (T. Bora, 2017b, s. 260) itmiştir, gözde meslek iste gelecekte iyi gelir getirecek, iş olanakları yüksek, muhtemelen fennî bir disiplindir. Disiplinlerinden mezun olduktan sonra ya çalıştıkları disiplinleri ile ilgili işlerde mutlu olamamış ya da hiç çalışmamış olsalar bile kendilerini disiplinlerine asla ait hissetmemişlerdir. Bu durum, basit bir "iş beğenmeyen orta sınıf” (Erdoğan, 2017, s. 100) anlatısına indirgenmemelidir; bir hayalin peşinden yeni bir eğitime başlamak elbette sınıfsal bir pratiktir, bir önceki bölümde ortaya serildiği üzere ekonomik sermayeden bağımsız değildir, ancak şımarıkça bir beğenmezlikten öte katlanılmaz bir yaşam hissinden ileri gelir. Öte yandan, Esra örneğinde görüldüğü gibi, disiplinlerini çok isteyerek tercih etseler dahi yaşadıkları iş bulamama problemi onları bu tercihlerinden soğutmuş görünmektedir.

\section{3."İkinci Şanslar": Yeni Lisans Disiplinlerinin Tercih Edilme Sebepleri}

Bu bölümde, mezun oldukları disiplinlerinden veya devamındaki iş tecrübelerinden memnun olmayan katılımcıların yeni disiplinlerini neden seçtikleri anlaşılmaya çalıșılmıştır ve burada özellikle "iş olanakları", "ideallerimdeki/ hayallerimdeki meslek" ve "yeni şeyler öğrenmek/kendini geliştirmek" temaları öne çıkmıştır. Daha önce de bahsedildiği gibi Esra mezun olduğu siyaset bilimi disiplinini çok sevmektedir, ancak iş olanaklarının eksiği ve KPSS sınavının zorluğu onu yeniden lisans okumaya yönlendirmiştir, Esra bu tercihini okul öncesi öğretmenliği disiplininden yana kullanmıștır. Esra, "İş olanağından ziyade, çocukları çok seviyorum. Düşündüm... Eee... İleride mutlu olabileceğim tek meslek..." diyerek bu mesleği seveceğini işaret etmekte, ancak "İş garantili tek meslek..." diyerek iş olanaklarını vurgulamaktadır. Ayrıca tekrar KPSS'ye gireceğini, bu defa daha ümitli olduğunu da ifade etmekte ve "Atanma şansı daha yüksek. Özelde çalışma olanağı fazla." diye de eklemektedir. Daha önce işletme bitirip bir mali müşavirin yanında çalışan ancak işinden tatmin olamayan Çağla da Esra gibi okul öncesi öğretmenliği disiplinini tercih etmiş ve yine tıpkı Esra gibi "Çocukları seven ve onlarla iyi anlaşan biriyim. Bu bölümü severek okuyabileceğimi düşündüm." demekte ve eklemektedir, "İş imkânının da olması bu bölümü seçmemde etkili.” Çağla ve Esra, neo-liberal sistem ve bilgi toplumunun bir yansıması olan "yaşam boyu eğitim" düşüncesinin bireyler üzerine yüklediği baskıyı ilk elden hissetmektedirler; tıpkı Güllüpınar'ın (2017) bahsettiği gibi bir işe, gelire, veya en azından bir iş olanağına sahip olabilmek adına önceki disiplinlerini sevseler de sevmeseler de yeniden üniversite okumaktadırlar.

Hande, Ece ve Demet ise daha çok kendilerini geliştirmek, yani kültürel sermaye artırımı amacıyla Arkeoloji (Hande) ve Sanat Tarihi (Ece ve Demet) disiplinlerini tercih etmişlerdir. Burada dikkat çeken nokta, Hande ve Ece'nin çalışıyor ve görece iyi gelirlere sahip olması, Demet'in ise her zaman geri dönebileceği kabin görevliliği gibi bir mesleğinin bulunmasıdır, yani ekonomik sermayeleri. Hande "Sosyal bilimlere hep ilgim vardı. Ben lisede okurken sosyal bilimler tembellerin ilgilendiği alanlar olarak görülürdü. (...) Sonra sadece hobi gibi öğrenmektense lisans eğitimi alarak hayatın başka alanları hakkında bilgi sahibi olmaya karar vererek sinava girdim. Arkeolojinin sorularıma yanıt olacağını düşündüm." demekte ve bu sözleriyle bir yandan da modern eğitim anlayışının "fennî" alanlara önem vermesi düşüncesini eleştirmektedir. Ece de basit- 
çe kendini geliştirme amacını "Başlama kararını verirken aklımda aslında bu bölüm yoktu. Biraz kendimi zorlamak istedim. Böyle bir kültür bölümü tercih sebebim, üniversite haricinde bu bilgiye erişmek için çok fazla çaba sarf etmem gerekecek olmasıydı." biçiminde ifade etmekte ve tıpkı Hande gibi bir yandan da "uzmanlık" disiplinlerinin öne çıktığı çağımızda "kültür” disiplini okumanın bir tür lüks olduğuna göndermede bulunmaktadır. İş arkadaşlarının entelektüel ilgi eksikliğinden şikâyet eden Demet ise çalıştığı zamanlar sinema ve televizyon okumak için s1nava girmiş, kazanamayınca sınava tekrar girmiş bu defa tarih okumak istemiş ancak puanı yetmeyince sanat tarihi disiplinine yönelmiştir, Orta Çağ tarihine çok ilgili olduğunu söyleyen Demet'in "kültürel”, "edebî" bir disiplin ve entelektüel gelişim aradığı açıktır; zaten kendisi de "Belki de böyle entelektüel açıdan beni geliştirebilecek bir bölüm olduğu için tercih ettim." demektedir.

Öte yandan sosyoloji eğitimini bir "gençlik hülyası" olarak gören Buket, psikoloji eğitimi ile ideal mesleğine kavuştuğunu söylemiş ve çocukluğundan beri bunu istediğini şu sözleriyle işaret etmiştir:

\section{"Psikiyatrik rahatsızliğl olan bir annem ve bir babam vardl. Çocukluğum onların psikolojik durumların kavramak ve onla- rı dengelemeye çalışmakla geçti. (...) Tüm bunlar beni insanlar anlamaya ve onlara iyi gelme çabasına yöneltti. (...) Kim oldu- ğumu biliyorum, kendimi gerçekleştirmek için, toplumda bana uygun bir yer edinmem şart. Klinik psikolog ve akademisyen olmak benim insanlara ve topluma faydalı olabil- mem için en iyi yol. Kendimi buna mecbur hissediyorum."}

Peki, iş olanakları, kendilerini geliştirme ve ideal mesleklerine kavuşma gibi sebeplerle bu yola çıkan katılımcılar bu yeni disiplinlerinden mezun olduklarında ne yapmayı düşünmektedirler, yani gelecek planları nedir? Siyaset biliminden okul öncesi öğretmenliğine geçen Esra daha önceden de "Yine KPSS'ye gireceğim. Atanma şansı daha yüksek." cümleleriyle iş olanaklarını vurgulamasının üzerine "Yüksek lisans yapmayı düşünüyorum öncelikle ve... iş hayatına atılmayı düșünüyorum." demektedir. Önceden işletme mezunu olan ve tıpkı Esra gibi iş olanakları sebebiyle okul öncesi öğretmenliğini tercih eden Çağla da “Önce alanımla ilgili KPSS’yi deneyeceğim. Olmazsa özel anaokullarında, rehabilitasyon merkezlerinde çalışmayı düşünüyorum." diyerek yeni disipliniyle ilgili bir mesleğe başlamayı ümit etmektedir. Sosyoloji eğitiminin ardından ideal mesleği olan psikoloji eğitimine başlayan Buket "Klinik psikolog ve akademisyen olmak istiyorum. Kararlıyım." diyerek anlatımını kuvvetlendirmektedir. Kabin hizmetleri mezunu ve şu an sanat tarihi okuyan Demet ise karamsardir;

\section{"Müzecilik yapmak istiyorum. Kendi bölü- mümün mesleğini yapmaya çalışacağım. Ama gel gör ki sanat tarihi bölümünden mezun olunca atamalarin bu kadar kisitl olmasi... KPSS gibi bir engel var önümde."}

Burada KPSS temasının yaygın olduğu görülebilecektir. T. Bora'nın (2017b, s. 272) da ifade ettiği gibi öğrenciler “KPSS'ye sığınmaktadır”lar, ancak KPSS doğrudan atanma ve iş garantisi sağlamamaktadır. Esra ve Çağla gibi bazı öğrenciler kurumsallaşan "sürekli eğitim” anlayışının "sürekli sınav rejimi"nin (s. 273) içine çekilmekte, sınavı daha kolay kazanabileceklerini ve daha kolay atanabileceklerini umdukları disiplinlere yönelmektedirler. Demet ise bu yaygın kaygıyı yeni disiplininde ilk defa yaşamaktadır. Bu bağlamda, ikinci kere lisans eğitimine kayıt olma sorunsalı gerçekten de bir istihdam problemi gibi görünmektedir.

Öte yandan, zaten birer mesleğe ve görece iyi birer gelire sahip Hande ve Ece ise daha farklı planlara sahiptir. Örneğin ekonomi mezunu ve şu an sanat tarihi okuyan Ece editörlük yapmaktadır ve sanat tarihi ile ilgili bir meslek edinmek gibi bir derdi yok gibi görünmektedir, bunun yerine "Bu alandaki kitapların editoryal çalışmalarında yer almayı düşünüyorum." diyerek mevcut mesleğine bir ekleme planlamaktadır. Uzman diş hekimi olan ve şu an kendini geliştirmek sebebiyle arkeoloji okuyan Hande ise "Yani gelecek planlarımı burada edindiklerimi ekleyerek yapmaya çalışıyorum. Evet, bu alanla ilgili bir mesleğe geçiş yapmayı çok isterim." demekte, ancak çok vurgulu

Tablo 2. Katılımcılar ve Not Ortalaması Değişimleri

\begin{tabular}{|c|c|c|c|c|c|}
\hline KATILIMCI & $\begin{array}{l}\text { İLK BITIRILEN YÜKSE- } \\
\text { KÖĞRETIM PROGRAMI }\end{array}$ & $\begin{array}{l}\text { MEZUNIYET NOT ORT. } \\
(\mathrm{Not} / 4)\end{array}$ & $\begin{array}{l}\text { ŞIMDIKI LISANS } \\
\text { PROGRAMI }\end{array}$ & $\begin{array}{c}\text { MEVCUT NOT } \\
\text { ORT. } \\
(\mathrm{Not} / 4)\end{array}$ & $\begin{array}{l}\text { NOT ORT. ARTIŞI } \\
(\text { Not/4) }\end{array}$ \\
\hline Esra & Siyaset Bilimi & $3.03 / 4$ & $\begin{array}{c}\text { Okul } \\
\text { Öncesi Öğr. }\end{array}$ & $3.03 / 4$ & $0.00 / 4$ \\
\hline Demet & $\begin{array}{l}\text { Sivil Havacılık } \\
\text { (Ön Lisans) }\end{array}$ & $3.08 / 4$ & $\begin{array}{l}\text { Sanat } \\
\text { Tarihi }\end{array}$ & $3.34 / 4$ & $0.26 / 4$ \\
\hline Ece & Ekonomi & $2.24 / 4$ & $\begin{array}{l}\text { Sanat } \\
\text { Tarihi }\end{array}$ & $3.25 / 4$ & $1.01 / 4$ \\
\hline Buket & Sosyoloji & $2.00 / 4$ & Psikoloji & $3.00 / 4$ & $1.00 / 4$ \\
\hline Hande & Diş Hekimliği & $3.37 / 4$ & Arkeoloji & $3.76 / 4$ & $0.39 / 4$ \\
\hline Çağla & İşletme & $2.84 / 4$ & $\begin{array}{c}\text { Okul } \\
\text { Öncesi Öğr. }\end{array}$ & $3.48 / 4$ & $0.64 / 4$ \\
\hline ORTALAMA & - & $2.76 / 4$ & - & $3.31 / 4$ & $\begin{array}{c}0.55 / 4 \\
(13.75 / 100)\end{array}$ \\
\hline
\end{tabular}


bir anlatım sunmamakta ve planlarını daha çok mevcut iş temposunu azaltmak üzerine inşa etmektedir.

Katılımcıların hemen hepsi, ya önceki eğitimlerini bitirir bitirmez ya da arada en fazla bir yıllık iş tecrübesinin ardından yeni eğitimlerine başlamışlardır. Yalnızca Hande uzun yıllar diş hekimliği eğitim ve mesleğini bir arada götürmüş ve ardından arkeolojiye kayıt olmuştur.

Katılımcıların önceki üniversiteleri ve şimdiki üniversiteleri arasındaki not ortalamaları arasındaki fark da önemlidir. Katılımcıların yeni disiplinlerindeki not ortalaması, eski disiplinlerindeki not ortalamalarından ortalama 4 üzerinden 0.55 puan (100 üzerinden 13.75 puan) daha fazladir (Tablo 2), bu bulgu Winter ve Harris'in (1999) bulgusuna da oldukça paralel görünmektedir. Bu kadar dar bir örneklem ile genelleme yapılamayacaksa da, hiçbir katılımcının en azından eskisine nazaran daha düşük bir not ortalamasına sahip olmayışı dikkate değerdir.

Yani katılımcılar yeni disiplinlerinde gerçekten de daha başarılıdırlar ve mezun olduklarında bu yeni mesleklerini belki de eski mesleklerinden çok daha iyi biçimde icra edebileceklerdir. Bu bulgu, bu tip öğrencilerin "başarısız" kimseler oldukları inanışını boşa çıkarır.

\section{TARTIŞMA VE SONUÇ}

$\mathrm{Bu}$ araştırma Türkiye'de sayıları yıldan yıla artan daha önceden bir yükseköğretim programını bitirmiş ve bugün tekrar örgün lisans eğitimine başlamış öğrencileri incelemeyi hedeflemiştir. Bu çerçevede öncelikle bu öğrencilerin kim olduklarını göstermeyi, onların demografik, ekonomik ve toplumsal niteliklerini betimlemeyi amaçlamış, bu öğrencilerin, eğitime dair hâkim bakış açısına, fayda, başarı ve gelir beklentilerine ve görece ileri yaşlarına rağmen verdikleri bu cesaret isteyen kararlarının -Bourdieu'nün kavramlarıyla- ekonomik, toplumsal ve kültürel sermayeleri ile ilişkisi olup olmadığını aramıştır. Öncelikle, öğrencilerin ileri yaşlarını, yani "alışılmadık” birer öğrenci oluşlarını, bir avantaj olarak gördükleri; genç yaşlarında eğitime dair hâkim bakış açısından, ailelerinden, diploma ve fayda beklentilerinden, hatta "kültürel/edebî" disiplinler yerine "fennî uzmanlık" disiplinlerine -yanlışyönlendirilişlerinden şimdi olduğu kadar rahat sıyrılamayacaklarını düşündükleri ortaya çıkmıştır. Cinsiyet bağ- lamı dikkat çekicidir; araştırmanın katılımcılarının hepsi kadındır ve hemen hepsi erkek olsalar bu kararı veremeyeceklerini belirtmektedirler, toplumdaki eğitime dair hâkim bakış açısı, erkekleri en yüksek gelire ulaşabilecekleri "teknik" disiplinlerden hizla mezun olmaya kadınlardan daha çok itiyor ve kadınlarınsa eğitimlerini uzatmalarını daha hoş karşıllyor görünmektedir.

Katılımcıların hemen hepsi bir şekilde yakınlarının hem ekonomik hem de toplumsal desteğini alarak iş ve ev sorumluluklarından sıyrılabilmiş veya çalışan, kendi çalışma zamanlarını ayarlayabilen ve gelirleri iyi olan öğrencilerdir. Yani katılımcıların her biri ya tekrar üniversite okumak ve ev için sorumluluklarını aşmak için gerekli ekonomik sermayeye sahiptir; ya da yakınlarından aldıkları günlük sorumlulukları bağlamındaki desteğe, yani toplumsal sermayeye. Yani ikinci kez lisans eğitimine başlayabilme kararı, bugün Türkiye'de okuduğu disiplinden memnun olmayan birçok öğrencinin sahip olmadığını varsayabileceğimiz vakit ve nakit ile ilişkilidir ve belki bu konumda olan diğer öğrenciler de yeterli sermaye birikimine ulaştıklarında benzer kararlar verebileceklerdir. Dahası, hemen tüm katılımcılar ikinci kere üniversite okuma fikrinin ailelerinden veya eşlerinden çıktığını ifade etmişlerdir, yani bu öğrenciler -hâkim olduğunu varsayabileceğimiz Habitus'ün aksine- böyle bir karar vermeye uygun birer Habitus'ün içinde yaşamaktadırlar.

Katılımcılardan biri (Esra) hariç hepsi ilk yükseköğretim disiplinlerinin "yanlış" birer tercih olduğunu ifade etmekte ve bu "yanlış" tercihlerini çoğunlukla aileleri, öğretmenleri veya sistem tarafindan yanlış yönlendirilmelerine bağlamaktadırlar. Elbette bu "yanlış" tercihler, mevcut ekonomik yapıdan bağımsız olmayan, gelecekte iyi kazandıracak "gözde" meslekler doğrultusunda yapılmış tercihlerdir. Ayrıca katılımcıların hemen hepsi okul yaşamları -veya ardından gelen iş yaşamları- boyunca ya bu ilk disiplinlerine ait hissetmemiş ya da işlerinde tatmin olamamışlardır (Katılımcıların araştırmanın temaları bağlamındaki özet hikâyeleri için bkz. Tablo 3). Okul terk konulu araştırmalardan da görülebileceği üzere bu temalar aslında ciddi birer "okul terk" sebebidir, ancak bu öğrenciler okullarını terk etmemiş, mezun olmuş, hatta bir kısmı mezun oldukları disiplin ile ilgili birer iş bile bulmuşlardır.

Tablo 3. Katılımcıların Araştırmanın Temaları Bağlamında Hikâyeleri

\begin{tabular}{|c|c|c|c|c|c|}
\hline \multirow[b]{2}{*}{ KATILIMCI } & \multicolumn{2}{|c|}{ Önceki Yükseköğretim Programına Dair; } & \multicolumn{3}{|c|}{ Şimdiki Örgün Lisans Programına Dair; } \\
\hline & Tercih sebepleri neydi? & Neden Yanlış Tercihti? & $\begin{array}{l}\text { Bu fikre nasıl kapıl- } \\
\text { dılar? }\end{array}$ & Tercih sebepleri nedir? & $\begin{array}{c}\text { Bu alanda çalışma } \\
\text { istekleri; }\end{array}$ \\
\hline ESRA & İsteyerek & - & İşsizlik endişesi & İş fırsatları & Kesinlikle \\
\hline DEMET & İş olanakları & $\begin{array}{l}\text { Disiplin hakkında önceden } \\
\text { yeterince bilgilendirilmeme }\end{array}$ & $\begin{array}{l}\text { İş hayatındaki tat- } \\
\text { minsizlik }\end{array}$ & Kendini geliştirmek & Belki \\
\hline BUKET & Gençlik ideali & $\begin{array}{c}\text { Yanlış yönlendirilme } \\
\text { (Öğretmen) }\end{array}$ & Ait hissetmeme & İdealindeki meslek & $\begin{array}{c}\text { Kesinlikle (Akademik } \\
\text { kariyer) }\end{array}$ \\
\hline ECE & İş olanakları & Yanlış yönlendirilme (Aile) & Ait hissetmeme & Kendini geliştirmek & İstemiyor \\
\hline ÇAĞLA & \multicolumn{2}{|c|}{ Puanı yettiği için } & $\begin{array}{l}\text { İş hayatındaki tat- } \\
\text { minsizlik }\end{array}$ & İş fırsatları & Kesinlikle \\
\hline HANDE & Gençlik ideali & $\begin{array}{c}\text { Yanlış yönlendirilme (Aile } \\
\text { ve sistem) }\end{array}$ & Ait hissetmeme & Kendini geliştirmek & Belki \\
\hline
\end{tabular}


Katılımcıların okullarını terk etmeyişlerinin sebebi işlevselci eğitim bakış açısında veya okul terk araştırmalarında bahsedildiği gibi üniversiteye çok iyi entegre oluşlarından ileri gelmemektedir; aksine bu "topluma faydalı birey" yetiştirme düşü, neden olduğu baskılar sonucunda, faydasız ve başarısız toplum üyeleri üretmiş ve bu öğrenciler -yeterli ekonomik veya toplumsal sermaye birikimine ulaşır ulaşmaz- "faydalı" ve "başarılı" olabilecekleri farklı birer disiplin arayışlarına çıkmışlardır. Öte yanda ise; çok severek başladıkları ve faydalı olabileceklerine inandıkları disiplinlerini, kariyerlerini, iş bulamayacakları ve atanamayacakları korkularıyla terk eden öğrenciler vardır, ki bu öğrenciler bilgi toplumu ve neo-liberal sistemin yarattığı, gelir elde edebilmek adına "yaşam boyu öğrenme" (Güllüpınar, 2017) ve hatta Collins'in (2011) de bahsettiği "yeterlilik enflasyonu" baskılarını üzerlerinde hissetmekte, bu bağlamda "kültürel" kariyerlerini terk etmek ve "uzmanlık" disiplinlerine yönelmek zorunda kalmaktadırlar veya belki de T. Bora'nın (2017a) da belirttiği üzere işsiz görünmemek için eğitimlerini uzatmak...

Katılımcıların ikinci lisans disiplinlerini tercih sebepleri incelendiğinde ise; iş olanakları haricinde, kendini geliştirme, yani kültürel sermaye artırma isteği ve ideallerdeki mesleği arayış teması ortaya çıkmıştır. Tüm o baskıların ardından, neticede idealdeki mesleğin eğitimine başlayabilmek, tam da bu araştırmanın ana problemini oluşturan hayallerin peşinden çıkılan ikinci şans arayışının nihayete ermesidir, ancak sonuç olarak bu temanın o kadar da baskın bir tema olmadığı görülmüştür. Kendini geliştirmek teması ise çok daha baskındır; bir önceki disiplinlerine asla ait hissetmemiş ancak bir şekilde geçimlerini de sağlamayı başarabilmiş bu öğrenciler, firsat bulduklarında, gelecek planlarında yer vermeyecek de olsalar, eski tutkularının peşinden hep okumayı istedikleri o disiplinleri kazanıp kaydolmaktadırlar. Bu sonuçlar katılımcıların gelecek planlarına da yansımaktadır; iş olanakları nedeniyle yeniden üniversiteye başlayan katılımcılar yeni mesleklerini kesinlikle benimsemektedirler, sonunda ideal mesleğinin eğitimine başlayan katılımcılar da alanlarının akademik çevrelerine girene kadar çabalayacaklarını belirtmişlerdir, kendilerini geliştirmek isteyenlerse bu yeni alanlarıyla ilgili bir meslekte ya hiç çalışmayacak ya da belki çalışacaklardır.

Sonuç olarak; önceden bir yükseköğretim programını bitirmiş ve bugün tekrar örgün lisans eğitimine başlamış öğrencilerin bir kısmının, yaygın anlatıda değinilen, sevdikleri, başarılı olacaklarına inandıkları veya geçmişte gözde olduğu için tercih ettikleri disiplinleri, kariyerleri terk etmek zorunda kalan ve ekonomik nedenlerle $i s ̧$ bulabilecekleri bir disipline yönelen, eğitimlerini uzatan öğrenciler oldukları şüphesizdir. Diğer yandaysa; geçmişte eğitim sisteminin, toplum ve ailelerinin baskıları nedeniyle yanlış tercihler yapan ve firsatını bulur bulmaz hayalleri olan disiplinlerde yeniden okumaya başlayan öğrenciler yer almaktadır. Bu firsatın, bu "ikinci şans"ın, ekonomik veya toplumsal sermaye, yani gelir ve destek ile olan ilişkisi açıktır. “Topluma faydalı birey” yetiştirme düşü ve baskısının ürettiği bu faydasız kimseler, hep toplumda faydalı olabilecekleri bir yerin hayalini kurmuş ve bu yeri bulduklarında gerçekten de öncesinden daha başarılı olmuşlardır. Sorunsal gerçekten de bir istihdam problemine indirgenmemelidir; meslekleri ve iyi birer gelirleri olmasına rağmen yeniden üniversiteye başlayıp, belki de sonucunda çok daha az gelir elde edebilecekleri ideal mesleklerinin eğitimini almaya karar veren öğrenciler de denklemin bir parçasıdır.

\section{KAYNAKÇA}

Bauman, Z. (2015). Akışkan modern dünyada kültür. (i. Çapcıoğlu ve F. Ömek, Çev.). Ankara: Atıf Yayınları.

Bean, J.P., \& Metzner, B.S. (1985). A conceptual model of nontraditional undergraduate student attrition. Review of Educational Research, 55(4), 485-540.

Beydağ, K.D., Gündüz, A., \& Özer, F.G. (2008). Sağlık meslek yüksekokulu öğrencilerinin eğitimlerine ve mesleklerine bakış açıları, meslekten beklentileri. Pamukkale Tıp Dergisi, 1(3), 137-142.

Bora, A. (2017a). Aile: En güçlü işsizlik sigortası. T. Bora vd. (Ed.), "Boşuna mı okuduk?" Türkiye'de beyaz yakalı işsizliği içinde (ss. 181-201). İstanbul: İletişim Yayınları.

Bora, A. (2017b). "Çalışmakla var olacağım gibi...” işsizin duygu dünyası. T. Bora vd. (Ed.), "Boşuna mı okuduk?" Türkiye'de beyaz yakalı işsizliği içinde (ss. 117-139). İstanbul: Illetişim Yayınları.

Bora, T. (2017a). “Herkes işsiz ama seninki farklı” Türkiye'de beyaz yakalı işsizliğine genel bir bakış. T. Bora vd. (Ed.), "Boşuna mı okuduk?" Türkiye'de beyaz yakalı işsizliği içinde (ss. 49-71). İstanbul: İletişim Yayınları.

Bora, T. (2017b). "KPSS'ye sığındım” İşsizler, seçme sınavları, stres ve adalet duygusu. T. Bora vd. (Ed.), "Boşuna mı okuduk?” Türkiye'de beyaz yakalı işsizliği içinde (ss. 259-273). İstanbul: Illetişim Yayınları.

Bottomore, T. (1971). Sosyoloji açısından eğitim. H. Topçuoğlu vd. (Ed.), Eğitim sosyolojisi (kaynak metinler) içinde (ss. 3257). Ankara: Ankara Üniversitesi Eğitim Fakültesi Yayınları.

Bourdieu, P. (1986). The forms of capital. In J.F. Richardson (Ed.), Handbook of theory and research for sociology education (pp. 46-58). Westport, Conn: Greenwood Press.

Bourdieu, P. (2012). The school as a conservative force: scholastic and cultural inequalities. In J. Eggleston (Ed.), Contemporary Research in the Sociology of Education (pp. 3246). London: Routledge.

Bourdieu, P. (2015). Ayrım beğeni yargııının toplumsal eleştirisi. Ankara: Heretik Basın Yayın.

Bourdieu, P., \& Wacquant, L. (2016). Düşünümsel bir antropoloji için cevaplar. İstanbul: İletişim Yayınları.

Bozkurt, V., \& Baştürk, Ş. (2016). Bilgi toplumu ve Türkiye. M. Zencirkıran, (Ed.)., Dünden Bugüne Türkiye'nin Toplumsal Yapısı içinde (ss. 405-420). Bursa: Dora Basım Yayın.

Collins, R. (2011). Credential Inflation and the Future of the Universities, Italian Journal of Sociology of Education, 2, 228-251. 
Durkheim, E. (1956). Education and sociology. New York: The Free Press.

Durkheim, E. (2014). Sosyolojik yöntemin kuralları. (Ö. Doğan, Çev.). Ankara: Doğu Batı Yayınları.

Durkheim, E. (2013). Intihar bir toplumbilim incelemesi. (Z.Z. Ilkgelen, Çev.). İstanbul: Pozitif Yayıncılık.

Erdoğan, N. (2017). Sancılı dil, hadım edilen kendilik ve aşınan karakter. T. Bora vd. (Ed.), "Boşuna mı okuduk?" Türkiye'de beyaz yakalı işsizliği içinde (ss. 75-115). İstanbul: İletişim Yayınları.

Finn, J.D. (1989). Withdrawing from school. Review of Educational Research, 59(2), 117-142.

Fortin, A., Sauve, L., Viger, C., \& Landry, F. (2016). Nontraditional student withdrawal from undergraduate a c counting programmes: A holistic perspective. Accounting Education, 25(5), 237-478.

Güllüpınar, F. (2017). Kamusallığın çöküşü ve bireyin sorumlulaştırılması olarak 'yaşam boyu öğrenme': eğitim v e istihdam politikalarının eleştirisine bir katkı. Amme İdaresi Dergisi, 50(1), 67-84.

Jordan, W.J., Lara, J., \& McPartland, J.M. (1994). Exploring the complexity of early dropout casual structures. Baltimore: Center for Research on Effective Schooling for Disadvantaged Students.

Karakaş, N.M., \& Özçelik, E.U. (2014). Evde hasta bakımı öğrencilerinin eğitimleri ve mesleğin geleceği ile ilgili görüşleri ve evde hasta bakımı programını tercih etme nedenleri. Inönü Üniversitesi Sağlık Hizmetleri Meslek Yüksekokulu Dergisi, 2(2), 22-28.

Kember, D. (1990). The use of a model to derive interventions which might reduce drop-out from distance education courses. Higher Education, 20(1), 11-24.

Kızılçaoğlu, A. (2003). Necatibey Eğitim Fakültesi sosyal bilgiler öğretmeni adaylarının profili. Balıkesir Üniversitesi Sosyal Bilimler Enstitüsü Dergisi, 6(10) 87-105.

Kümbetoğlu, B. (2012). Sosyolojide ve antropolojide niteliksel yöntem ve araştırma. İstanbul: Bağlam Yayıncılık.

Long, M., Ferrier, F., \& Heagney, M. (2006). Stay, play or give it away? Students continuing, changing or leaving university study in first year. Clayton, VIC: Centre for the Economics of Education and Training, Monash University.

Meyer, M., \& Marx, S. (2014). Engineering dropouts: A qualitative examination of why undergraduates leave engineering. Journal of Engineering Education, 103(4), 525-548.

Neuman, W.L. (2014). Toplumsal araştırma yöntemleri nitel ve nicel yaklaşımlar. Ankara: Yayınodası Yayıncılık.

Özbudak Akça, Y.B., Çakır Aydın, D. ve Halifeoğlu, F.M. (2018). Mimarlık mesleğine ulaşılabilirlikte farklı bir arayış denemesi: Dicle Üniversitesi örneği. Elektronik Sosyal Bilimler Dergisi, 67(17), 1147-1158.

Parsons, T. (1959). The school class as a social system: Some of its functions in American Society. Harvard Educational Review, 29(4), 297-318.

Rumberger, R.W. (2001, Jan). Why students drop-out of school and what can be done. Dropouts in America: How severe is the problem? What do we know about intervention and prevention? conference, Harvard University.
Şimşek, H. (2013). University students' tendencies toward and reasons behind dropout. Journal of Technical and Educational Sciences, 6(2), 242-271.

Tezcan, M. (1985). Eğitim sosyolojisi (4. Baskı). Ankara: Ankara Üniversitesi Eğitim Fakültesi Yayınları.

Tezcan, M. (2002). Postmodern ve küresel toplumda eğitim. Ankara: Anı Yayınevi.

Tinto, V. (1975). Dropout from higher education: A theoretical synthesis of recent research. Review of Educational Research, 45(1), 89-125.

Tinto, V. (1982). Limits of theory and practice in student attrition. Journal of Higher Education, 53(6), 687-700.

Winter, P.A., \& Harris, M.R. (1999). Community college reverse transfer students: A field survey of a nontraditional student group. Community College Review, 27(1), 13-29.

Withey, L., Fox, C.L., \& Hartley, J. (2014). "I cannot mess this up anymore": The experiences of undergraduates who withdraw and start again elsewhere. Psychology Teaching Review, 20(1), 78-89.

Yorke, M., \& Longden, B. (2008). The first-year experience of higher education in the UK - final report. York: Higher Education Academy. 